Article

\title{
Translocation of Cd and Mn from Bark to Leaves in Willows on Contaminated Sediments: Delayed Budburst Is Related to High Mn Concentrations
}

\section{Bart Vandecasteele $^{1, *}$, Paul Quataert ${ }^{2}$, Frederic Piesschaert ${ }^{2}$, Suzanna Lettens ${ }^{2}$, Bruno De Vos ${ }^{2}$ and Gijs Du Laing ${ }^{3}$}

1 Institute for Agricultural and Fisheries Research (ILVO), Scientific Institute of the Government of Flanders, Burg. van Gansberghelaan 109, B-9820 Merelbeke, Belgium

2 Research Institute for Nature and Forest (INBO), Scientific Institute of the Government of Flanders, Kliniekstraat 25, B-1070 Brussel, Belgium; E-Mails: paul.quataert@inbo.be (P.Q.);

Frederic.Piesschaert@inbo.be (F.P.); suzanna.lettens@inbo.be (S.L.); bruno.devos@inbo.be (B.D.V.)

3 Ghent University, Department of Applied Analytical and Physical Chemistry, Coupure 653, B-9000 Ghent, Belgium; E-Mail: Gijs.dulaing@ugent.be

* Author to whom correspondence should be addressed;

E-Mail: bart.vandecasteele@ilvo.vlaanderen.be; Tel.: +32-92-722-699; Fax: +32-92-722-701.

Academic Editor: Nicholas Dickinson

Received: 29 December 2014 / Accepted: 26 March 2015 / Published: 13 April 2015

\begin{abstract}
Changes in the hydrology of sediments in tidal marshes or landfills may affect the uptake of metals in the vegetation. Leaf and stem samples of Salix cinerea (grey sallow) were collected during four consecutive growing seasons at six contaminated plots on a polluted dredged sediment landfill and one plot on an uncontaminated reference site. The first three contaminated plots were already emerged in the first half of the first growing season, while the other three were submerged in the first year, but became increasingly dry over the study period. Foliar and stem cutting concentrations for $\mathrm{Cd}, \mathrm{Zn}$ and $\mathrm{Mn}$ increased on the latter three plots over the four years. Willow bark contained high concentrations of $\mathrm{Cd}, \mathrm{Zn}$ and $\mathrm{Mn}$. In two consecutive greenhouse experiments with willow cuttings from different origins (uncontaminated and contaminated sites) and grown under different soil conditions (uncontaminated and contaminated), we observed an important translocation of $\mathrm{Mn}$ from bark to shoots. In a third experiment with willow cuttings collected on soils with a range of heavy metal concentrations and, thus, with a broad range of $\mathrm{Cd}$ (4-67 mg/kg dry matter), $\mathrm{Zn}$
\end{abstract}


(247-660 mg/kg dry matter) and Mn (38-524 mg/kg dry matter) concentrations in the bark, high Mn concentrations in the bark were found to affect the budburst of willow cuttings, while no association of delayed budburst with $\mathrm{Cd}$ and $\mathrm{Zn}$ concentrations in the bark was found. We conclude that wood and, especially, bark are not a sink for metals in living willows. The high Mn concentrations in the bark directly or indirectly caused delayed or restricted budburst of the willow cuttings.

Keywords: ecotoxicity; riparian forests; wetland restoration; softwood floodplain forests; Salix; dredge-disposal impoundment; marsh to tidal woodland transition; intermittently flooded areas; water-table decline; sulfate leaching; phytoremediation; manganese toxicity

\section{Introduction}

Willow is well-suited for environmental applications, with increasing use for conservation and ecosystem restoration [1-3] or as a bioenergy crop [4,5]. In riparian vegetation, willows may dominate as a colonizer on sediments, but they can accumulate significant metal levels in roots and shoots when grown on contaminated sediments, thus causing ecological hazards [6]. Salix cinerea was found to be better adapted to wetlands and waterlogged environments in comparison with other willow species [7] or other tree species [8], probably due to the oxidizing activity of the roots [7,8]. Wetland plants must be able to tolerate high $\mathrm{Mn}$ and Fe availability in waterlogged soils $[9,10]$. Clear differences between willow species for plant uptake of Mn were also observed [7,11,12]. In previous research, we observed that the only effective management option for reducing the uptake of $\mathrm{Cd}$ and $\mathrm{Zn}$ by willow was submergence of contaminated calcareous dredged sediments, but this also resulted in elevated Mn uptake in willow $[13,14]$. The positive effect of flooding sediment-derived soils for reducing Cd uptake and the subsequent higher Mn uptake in softwood wetland plants was also observed by Bourret et al. [15]. Higher Mn concentrations in plants may interact with the uptake of other essential elements [16] and may cause toxicity [7,17-19].

Contaminated sites may be vegetated, and long-term changes in hydrology or other abiotic factors may affect the vegetation and its role in phytoremediation strategies. We present results for a contaminated dredged sediment landfill that underwent a significant drop in the water table level. This paper has two parts: observational and experimental. During a four-year period (2003-2006), we monitored the impact of dropping groundwater levels on the bioavailability of $\mathrm{Cd}, \mathrm{Zn}$ and $\mathrm{Mn}$. In two consecutive greenhouse trials (2005 and 2006), we investigated the pathway of these elements after being taken up from the soil into the plants. With a third experiment, we assessed the effect of bark concentrations of $\mathrm{Cd}, \mathrm{Zn}$ and $\mathrm{Mn}$ on budburst. The drastic change in hydrology over the four-year period provided an opportunity to observe the effect of hydrology on metal uptake in wetland shrubs. In the first two years, a dramatic effect on leaf concentrations in Salix cinerea was reported for this site, especially for the initially submerged plots [20]. Leaf and stem samples of $S$. cinerea were collected during four consecutive growing seasons at different plots with variable lengths of submersion in the first half of the growing season.

The first two greenhouse trials were conducted with cuttings of $S$. cinerea from plots with a different pollution status (uncontaminated and contaminated, i.e., with low and high $\mathrm{Cd}, \mathrm{Zn}$ and $\mathrm{Mn}$ concentrations in 
the bark, respectively). In the first trial, the cuttings were grown in the same soil conditions as their origin, and uptake of $\mathrm{Cd}, \mathrm{Zn}$ and $\mathrm{Mn}$ was monitored over a short period. The second trial was a factorial experiment, in which each cutting type (uncontaminated and contaminated) was planted in each of the soil conditions, and uptake of $\mathrm{Cd}, \mathrm{Zn}$ and $\mathrm{Mn}$ was monitored over a longer period. The third greenhouse trial studied the effect of $\mathrm{Cd}, \mathrm{Mn}$ and $\mathrm{Zn}$ concentrations in the bark on bud and shoot formation. Our hypothesis is that $\mathrm{Cd}, \mathrm{Zn}$ and $\mathrm{Mn}$ in the bark are translocated to the leaves and that this process is more important for foliar concentrations in the early growing season than uptake from the soil.

\section{Results and Discussion}

\subsection{Soil Properties and Groundwater Levels}

The sandy part of the landfill was characterized by lower concentrations of nutrients, heavy metals and total organic carbon (TOC) (Table 1). In the clay part of the landfill, differences between the drier and the wetter area were not remarkable in 2003, but in 2005, lower sulfate concentrations and electrical conductivity (EC) were measured for the drier part. Both parts had a similar degree of contamination with heavy metals (Table 1$)$. A strong positive correlation $(R=0.91, p<0.05)$ was observed between EC and sulfate in 2005. The soil profile of Plot 3 (Figure 1) shows increasing EC, sulfate and S concentrations with increasing depth, illustrating the tight relation between EC and sulfate concentrations and the process of sulfate leaching from the topsoil to deeper soil layers. No specific trend for $\mathrm{pH}$ was observed (Figure 1).

Table 1. Soil properties of the dredged sediment landfill site sampled on 23 points of a regular grid, grouped for the three parts of the site ("sandy part, dry": sandy part, already emerged in 2003; "clay part, dry": clay part, already emerged in 2003; "clay part, wet": clay part, still submerged in 2003). Values are averages, with standard deviation in brackets (TOC, total organic carbon; EC, electrical conductivity). Samples were taken in 2003, except for $\mathrm{S}, \mathrm{EC}$ and $\mathrm{SO}_{4}$, which were taken in 2005.

\begin{tabular}{ccccc}
\hline Soil Type & Sandy Part, Dry & Clay Part, Dry & Clay Part, Wet \\
\hline Samples & $\mathbf{3}$ & $\mathbf{1 1}$ & $\mathbf{9}$ \\
\hline Clay & & $11(4)$ & $40(7)$ & $45(5)$ \\
Silt & & $30(10)$ & $52(5)$ & $52(3)$ \\
Sand & $\%$ & $59(14)$ & $8(9)$ & $3(3)$ \\
$\mathrm{TOC}$ & & $1.9(2.4)$ & $3.6(1.2)$ & $5.1(1.2)$ \\
$\mathrm{CaCO}_{3}$ & & $8.4(1.6)$ & $11.5(2.6)$ & $12.5(1.1)$ \\
\hline $\mathrm{pH}-\mathrm{H}_{2} \mathrm{O}$ & $(-)$ & $7.8(0.2)$ & $7.5(0.1)$ & $7.6(0.1)$ \\
\hline $\mathrm{P}$ & & $2.3(0.6)$ & $3.5(0.9)$ & $4.0(0.8)$ \\
$\mathrm{K}$ & & $3.5(1.3)$ & $6.1(1.3)$ & $7.7(0.7)$ \\
$\mathrm{Ca}$ & $\mathrm{g} / \mathrm{kg}$ dry soil & $38.9(6.2)$ & $51.3(7.5)$ & $59.1(5.8)$ \\
$\mathrm{Mg}$ & & $2.2(0.7)$ & $4.1(0.9)$ & $5.2(0.5)$ \\
\hline
\end{tabular}


Table 1. Cont.

\begin{tabular}{|c|c|c|c|c|}
\hline Soil Type & & Sandy Part, Dry & Clay Part, Dry & Clay Part, Wet \\
\hline Samples & & 3 & 11 & 9 \\
\hline $\mathrm{Cd}$ & \multirow{10}{*}{$\mathrm{mg} / \mathrm{kg}$ dry soil } & $3.6(2.1)$ & $10.2(4.4)$ & $13.0(3.9)$ \\
\hline $\mathrm{Cu}$ & & $64(47)$ & $131(35)$ & $177(45)$ \\
\hline $\mathrm{Mn}$ & & $385(106)$ & $606(143)$ & $689(81)$ \\
\hline $\mathrm{Cr}$ & & $248(154)$ & $388(103)$ & $485(120)$ \\
\hline $\mathrm{Pb}$ & & $70(41)$ & $119(22)$ & $142(25)$ \\
\hline $\mathrm{Ni}$ & & $16(7)$ & $30(7)$ & $36(4)$ \\
\hline $\mathrm{Zn}$ & & $441(280)$ & $848(240)$ & $1077(269)$ \\
\hline As & & $8(3)$ & $14(3)$ & $18(2)$ \\
\hline S & & $495(185)$ & $1895(794)$ & $2502(416)$ \\
\hline S (2005) & & $873(555)$ & $1459(300)$ & $2232(783)$ \\
\hline $\mathrm{EC}$ & \multirow{2}{*}{$\mu \mathrm{S} / \mathrm{cm}$} & $113(57)$ & $460(374)$ & $469(242)$ \\
\hline EC (2005) & & $122(29)$ & $176(44)$ & $436(432)$ \\
\hline $\mathrm{SO}_{4}(2005)$ & $\mathrm{mg} / \mathrm{kg}$ dry soil & $77(90)$ & $81(119)$ & $342(229)$ \\
\hline
\end{tabular}

Below, we differentiate between the evolution of two parts of the site, i.e., between the plots that were already emerged in spring 2003 (“dry") and the plots initially still submerged in 2003 ("wet"). The data from the piezometers (Figure 2, Table 2) show small, but clear differences in the groundwater dynamics between the plots already emerged in 2003 (Plots 1-3) and the plots still submerged in 2003 (Plots 4-6). The initially submerged plots show a general decrease of the water levels of about $20 \mathrm{~cm}$ from 2003 to 2005, contrary to the already emerged plots, where no downward trend in the water levels is observed over the years. The amplitude of water level in the emerged plots is distinctly larger than in the initially submerged plots. In the emerged plots, water levels dropped deep below the surface level in summer, suggesting a well-aerated layer of topsoil during the growing season. The piezometer near Plot 1 , at the sandy inlet of the landfill, was dry during a large part of the year. Vegetation is probably not groundwater dependent here. The amplitude in Plot 5 is larger than expected, but this is probably because the piezometer representing this plot was located at the margin of the wet depression.

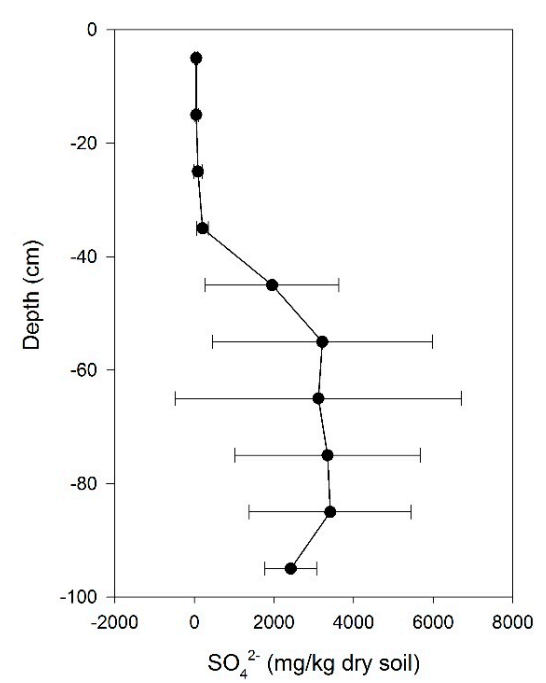

(a)

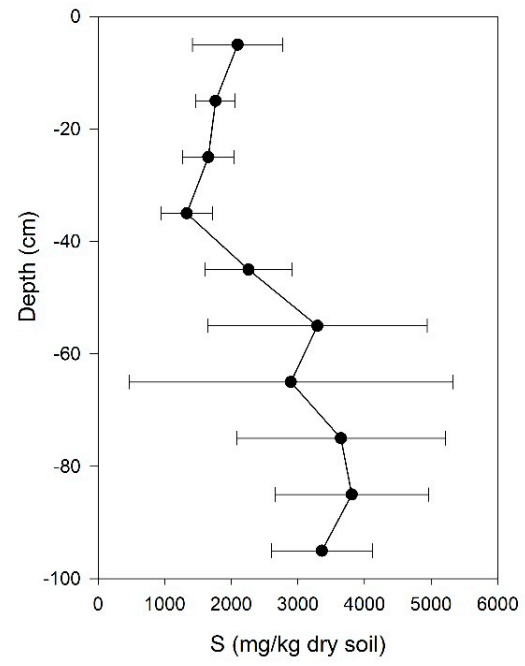

(b) 
Figure 1. Cont.

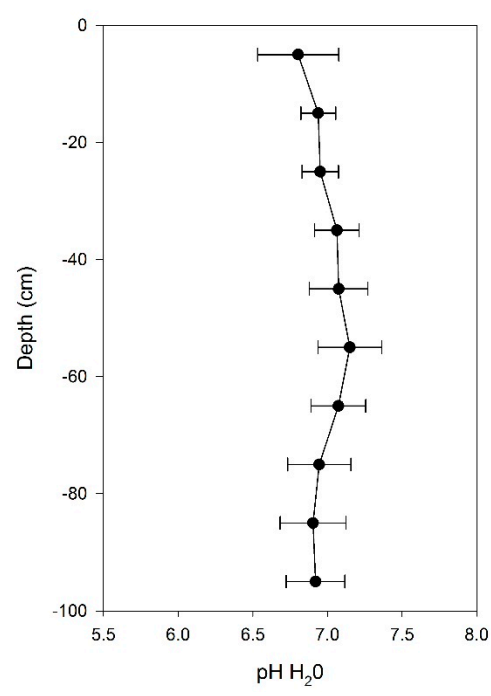

(c)

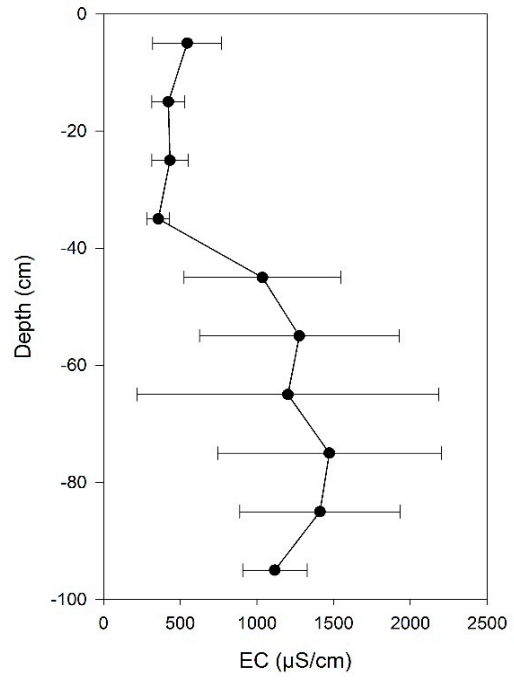

(d)

Figure 1. (a) Sulfate and (b) total S concentrations, (c) $\mathrm{pH}$ and (d) electrical conductivity (EC), measured in the soil profile at Plot 3 in fall 2005 and 2006 (values are averages for six replicates; error bars indicate standard deviation for six replicates).

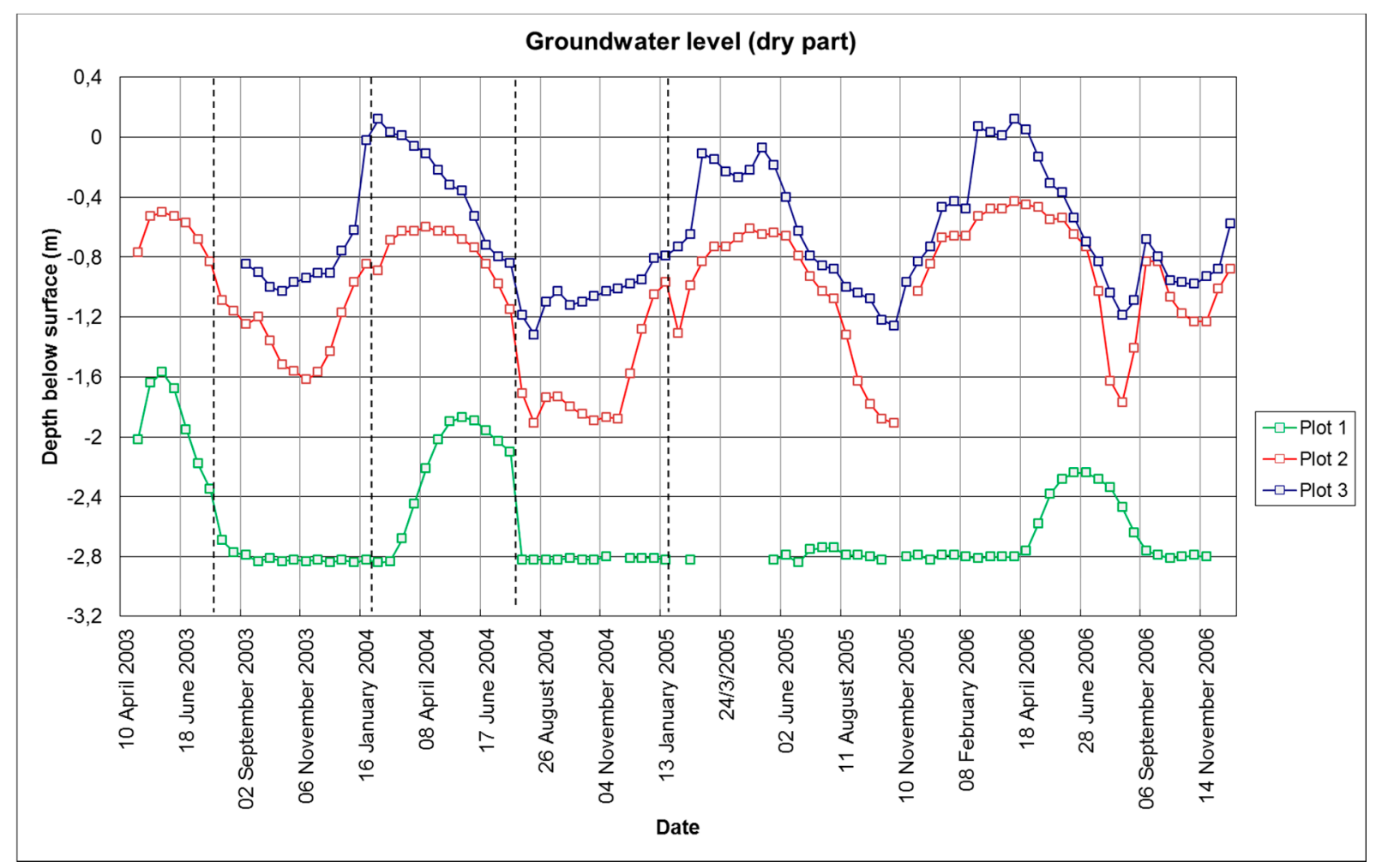

(a)

Figure 2. Cont. 


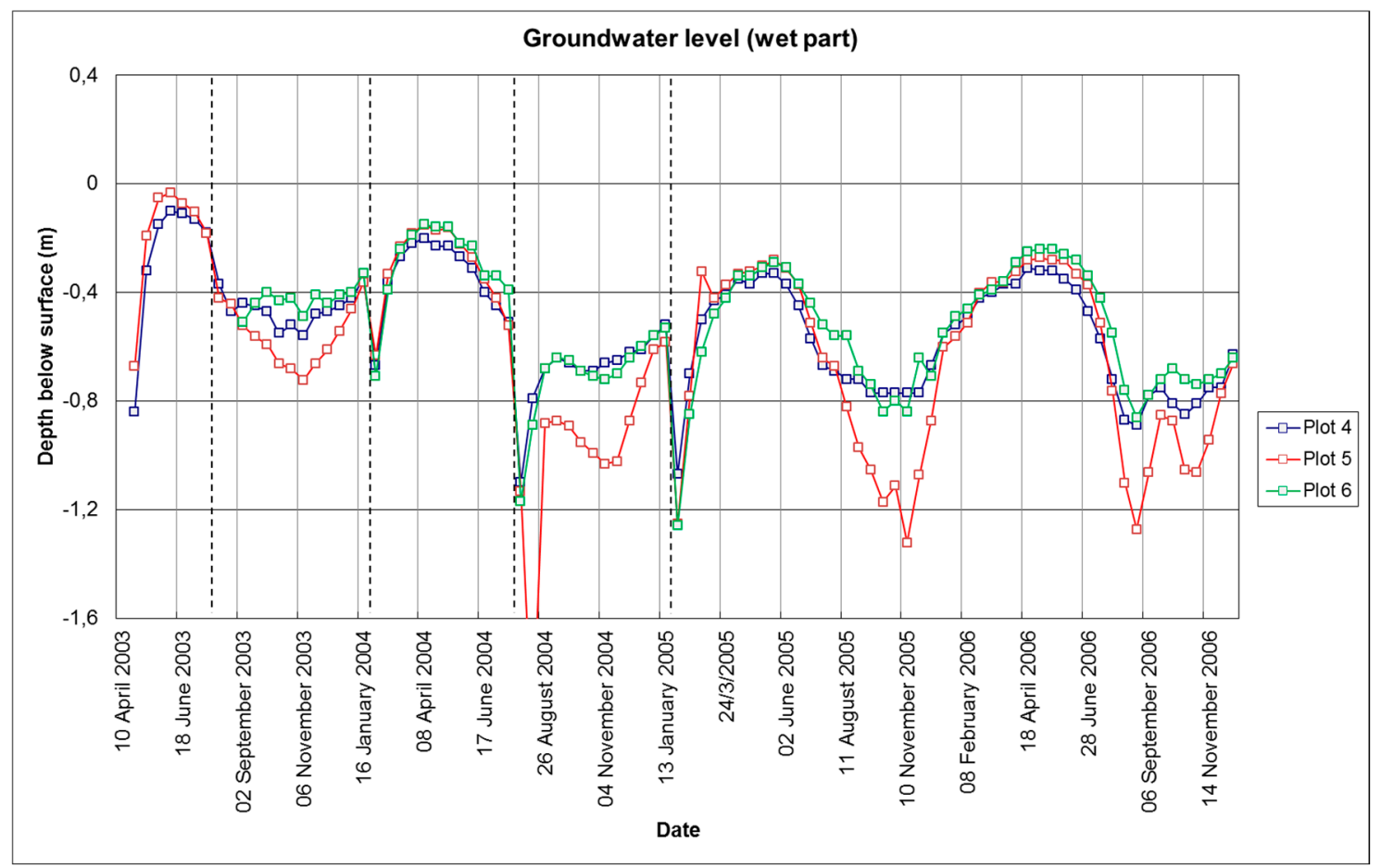

(b)

Figure 2. Time series of the groundwater levels in piezometers near the vegetation plots representative for (a) the drier (Plots 1-3, plots already emerged in 2003) and (b) wetter parts (Plots 4-6, plots still submerged in 2003) of the landfill. The dashed line indicates data of groundwater sampling disturbing the time series. The piezometer near Plot 1 was dry on a regular basis.

Table 2. Amplitude, (amp), minimal (min) and maximal (max) water depth (m) of piezometers closest to the plots used for the monitoring of metal uptake in the vegetation.

\begin{tabular}{|c|c|c|c|c|c|c|c|c|c|c|c|c|}
\hline \multirow{2}{*}{ Plot } & \multicolumn{3}{|c|}{2003} & \multicolumn{3}{|c|}{2004} & \multicolumn{3}{|c|}{2005} & \multicolumn{3}{|c|}{2006} \\
\hline & amp & $\min$ & $\max$ & amp & $\min$ & $\max$ & amp & $\min$ & $\max$ & amp & $\min$ & $\max$ \\
\hline 1 & & -1.57 & $<-2.84$ & & -1.87 & $<-2.84$ & & -2.74 & $<-2.84$ & & -2.24 & $<-2.84$ \\
\hline 2 & 1.12 & -0.50 & -1.62 & 1.29 & -0.60 & -1.89 & 1.30 & -0.61 & -1.91 & 1.34 & -0.43 & -1.77 \\
\hline 3 & & & & 1.10 & -0.02 & -1.12 & 1.19 & -0.07 & -1.26 & 1.31 & 0.12 & -1.19 \\
\hline 4 & 0.74 & -0.10 & -0.84 & 0.49 & -0.20 & -0.69 & 0.44 & -0.33 & -0.77 & 0.58 & -0.31 & -0.89 \\
\hline 5 & 0.69 & -0.03 & -0.72 & 0.88 & -0.15 & -1.03 & 1.04 & -0.28 & -1.32 & 1.00 & -0.27 & -1.27 \\
\hline 6 & 0.11 & -0.40 & -0.51 & 0.57 & -0.15 & -0.72 & 0.55 & -0.29 & -0.84 & 0.62 & -0.24 & -0.86 \\
\hline
\end{tabular}

\subsection{Metal Concentrations in Vegetation}

\subsubsection{Foliar Concentrations}

In the reference plot, the foliar concentrations for $\mathrm{Cd}, \mathrm{Zn}$ and $\mathrm{Mn}$ remained constant over the four-year period (Figure 3). Furthermore, there is no important seasonal pattern over the growing season. In contrast, the trends in the contaminated plots were complicated and depended on plot type ("dry", i.e., already emerged in 2003, or "wet", i.e., initially submerged in 2003, but emerging in the following years) and on heavy metal levels. 


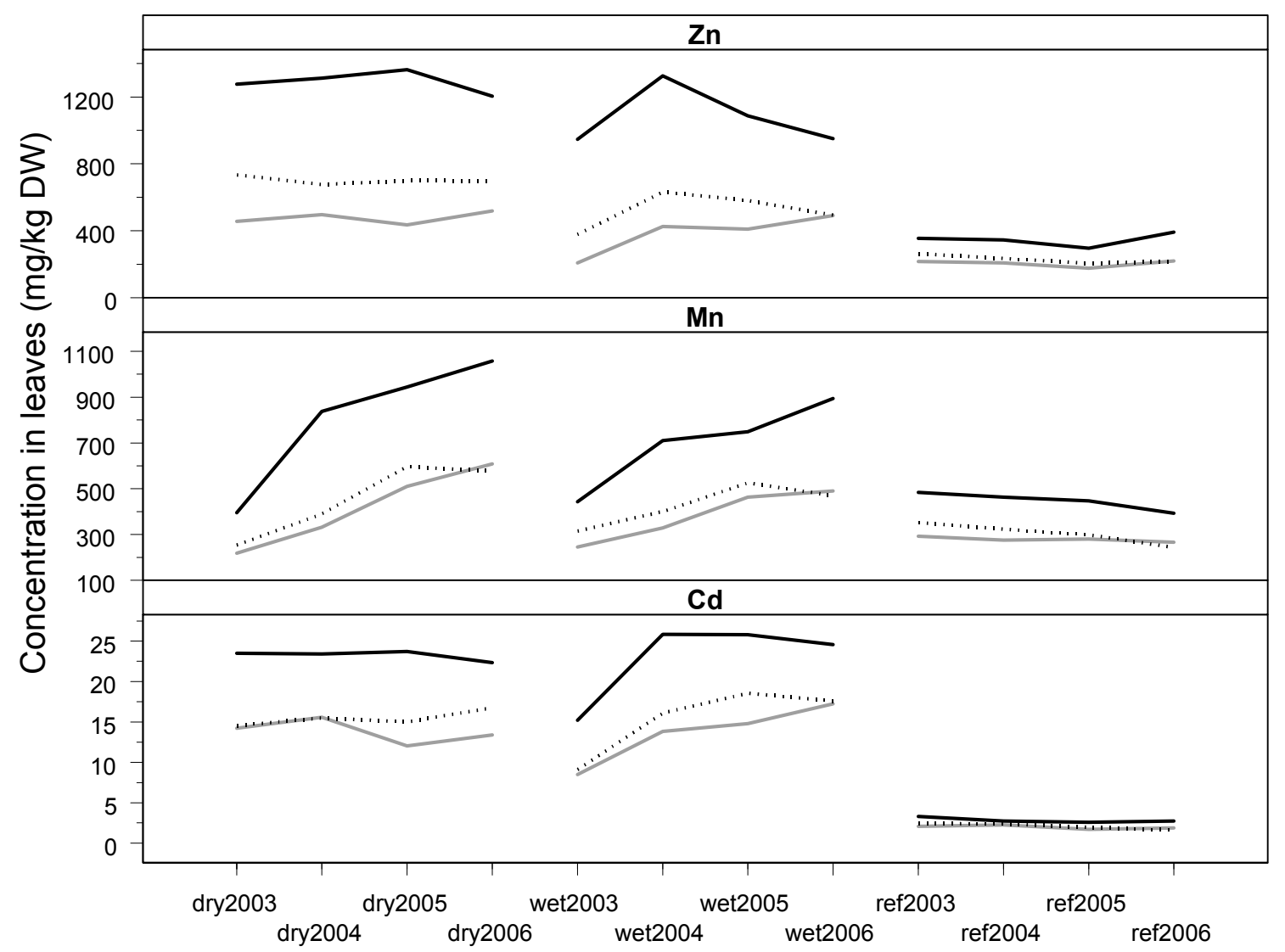

Figure 3. Trends in foliar concentrations between 2003 and 2006 in the early (gray line), middle (dotted line) and late growing season (black line) for $\mathrm{Cd}, \mathrm{Zn}$ and $\mathrm{Mn}$ for the reference plot (ref, Plot 0), the plots already emerged in 2003 ("dry", Plots $1+2+3$ ) and the plots still submerged in 2003 (“wet”, Plots $4+5+6$ ) (DW: dry weight).

As expected, in the initially submerged plots, the foliar concentrations increased between 2003 and 2004 (Figure 3). For Zn, the concentration decreased again after 2004, while the Cd concentrations remained at the same level, and the Mn concentrations increased further. In the dry plots, the foliar concentration of $\mathrm{Zn}$ and $\mathrm{Cd}$ remained equal, but for $\mathrm{Mn}$, the concentration increased. Hence, the most striking trend is the increase in Mn concentrations in both the dry and wet plots. Within the growing season, the trend of increasing concentrations for $\mathrm{Cd}, \mathrm{Zn}$ and $\mathrm{Mn}$ towards the end of the growing season was observed in the four years. For the emerged plots, no significant increase $(p>0.05)$ in $\mathrm{Cd}$ and $\mathrm{Zn}$ concentrations in the late growing season was found between 2003 and 2006. For the initially submerged plots, the measured Cd concentrations in 2003 were significantly lower $(p<0.01)$ than for the emerged plots, but concentrations increased significantly in the next three years, so that no significant differences were detected any longer when compared to the concentrations for the plots that were already emerged in 2003. Zn concentrations were significantly lower $(p<0.01)$ than for the emerged plot in 2003, 2005 and 2006, but not in 2004. The $\mathrm{Cd}$ and $\mathrm{Zn}$ concentrations were significantly lower for the reference plot than for the emerged plots during the four years of monitoring. Mn concentrations for both the submerged and the emerged plots were not significantly different $(p>0.05)$ from the concentrations at the reference plot in 2003, but increased to concentrations that were significantly higher than the reference plot from 2004 on. Strong positive correlations $(p<0.05)$ were found between $\mathrm{Cd}$ and $\mathrm{Zn}$ 
concentrations in the leaves, both for the dataset as a whole and for the sub-datasets per plot. In contrast, no significant correlation between $\mathrm{Mn}$ and Fe concentrations in the leaves was observed $(p>0.05)$. In conclusion, at the end of the four-year monitoring period, the foliar concentrations for $\mathrm{Cd}, \mathrm{Zn}$ and $\mathrm{Mn}$ were comparable for the initially submerged and the already emerged plots. A steady rise in $\mathrm{Mn}$ concentrations in the leaves of the trees on the dredged sediment landfill site were measured during each year's late growing season. This was noteworthy, as it represents a doubling of the Mn concentrations in 2006 relative to 2003 (Figure 3).

\subsubsection{Stem Cuttings}

Trends observed for the metal concentrations in the cuttings were element specific (Figure 4). For $\mathrm{Mn}$, concentrations increased over the four-year period for both the initially emerged and submerged plots. Zn concentrations were higher for the drier plots, intermediate for the initially submerged plots and lowest for the reference plot. Cd concentrations were more or less stable; they were higher for both the dry and the wet plots than for the uncontaminated reference. Cuttings for the sampling in fall 2006 were split up into bark and wood. The $\mathrm{Cd}, \mathrm{Zn}$ and $\mathrm{Mn}$ concentrations were clearly higher in the bark than in the wood and were higher for all plots on the landfill compared to the reference plot (Table 3).

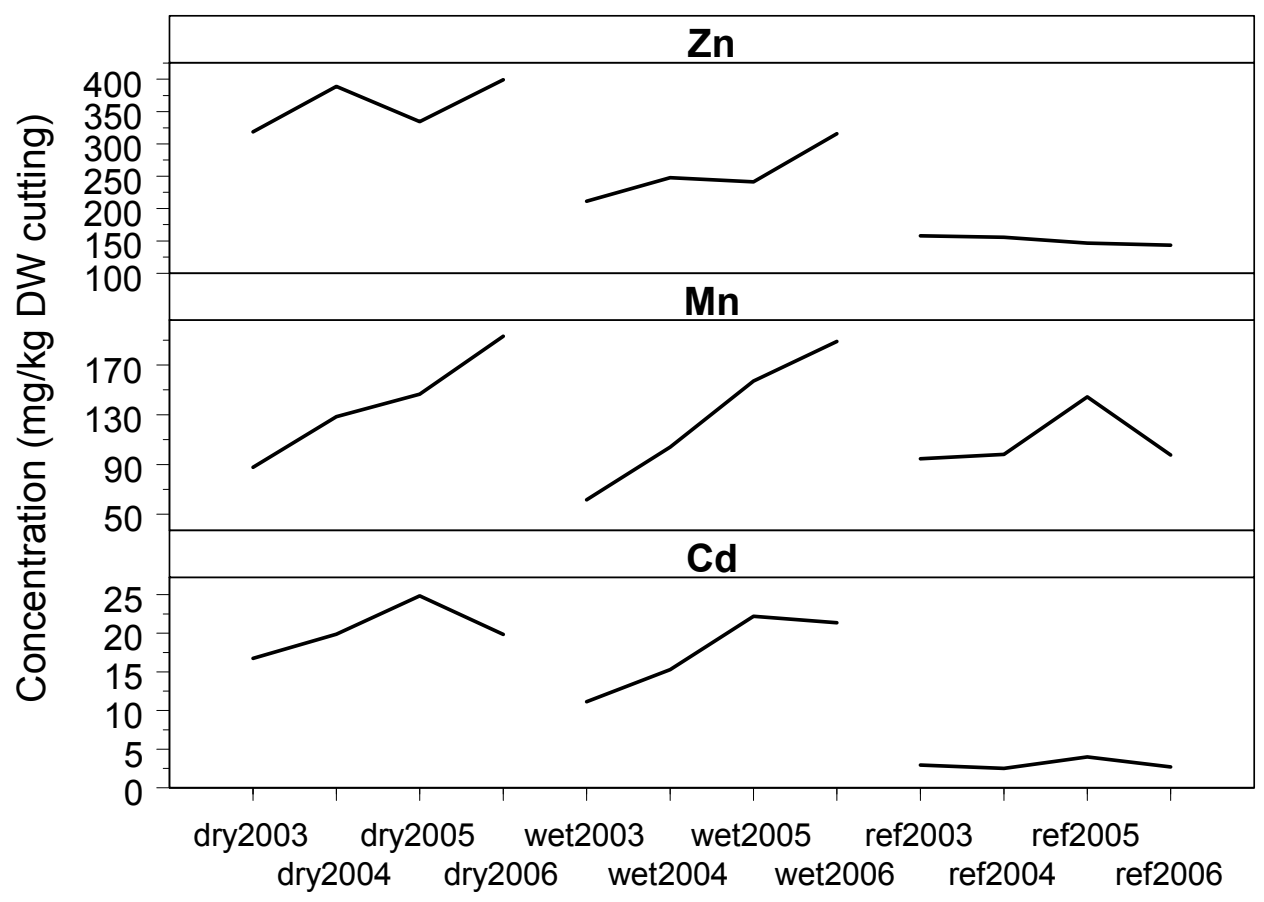

Figure 4. Trends between 2003 and 2006 in concentrations for Cd, $\mathrm{Zn}$ and $\mathrm{Mn}$ in the stem cuttings at the end of the growing season for the reference plot (ref, Plot 0), the plots already emerged in 2003 ("dry", Plots $1+2+3$ ) and the plots submerged in 2003 ("wet", Plots $4+5+6$ ) (DW: dry weight). 
Table 3. Concentrations for $\mathrm{Cd}, \mathrm{Zn}$ and $\mathrm{Mn}(\mathrm{mg} / \mathrm{kg}$ dry weight) in the bark and wood of cuttings for the reference plot (Plot 0), the plots emerged in 2003 (Plots $1+2+3$ ) and the plots still submerged in 2003 (Plots $4+5+6$ ) at the end of the growing season 2006. Values are the averages of 4 replicates per plot, with the standard deviations in brackets.

\begin{tabular}{ccccc}
\hline Part & Plot & Cd & Mn & Zn \\
\hline \multirow{6}{*}{ Wood } & 0 & $1.2(0.2)$ & $54(37)$ & $60(31)$ \\
& 1 & $8.7(5.5)$ & $55(50)$ & $294(150)$ \\
& 2 & $14.4(5.2)$ & $169(36)$ & $225(28)$ \\
& 3 & $11.5(1.8)$ & $139(33)$ & $147(39)$ \\
& 4 & $11.2(1.8)$ & $145(27)$ & $182(36)$ \\
& 5 & $12.2(3.1)$ & $110(27)$ & $186(57)$ \\
& 6 & $9.2(1.2)$ & $86(30)$ & $112(6)$ \\
\hline \multirow{6}{*}{ Bark } & 0 & $5.7(1.2)$ & $206(121)$ & $342(159)$ \\
& 1 & $30.9(15.1)$ & $157(97)$ & $1077(380)$ \\
& 2 & $53.1(19.4)$ & $489(136)$ & $883(248)$ \\
& 3 & $44.7(6.7)$ & $475(200)$ & $609(123)$ \\
& 4 & $44.6(11.1)$ & $457(73)$ & $679(107)$ \\
& 5 & $52.3(10.2)$ & $394(47)$ & $711(99)$ \\
& 6 & $39.9(9.5)$ & $282(45)$ & $588(63)$ \\
\hline
\end{tabular}

\subsection{Metal Translocation from Cuttings to Shoots during the First Weeks of the Growing Season}

In Greenhouse Experiment 1, we compared the distribution of $\mathrm{Cd}, \mathrm{Zn}$ and $\mathrm{Mn}$ across the bark, wood and shoots of the plants in the first weeks after planting cuttings for: (A) cuttings with low bark concentrations grown in uncontaminated soil; and (B) cuttings with high bark concentrations grown in contaminated soil. The soil from the contaminated site had higher concentrations for the heavy metals, but also for nutrients (Table 4). In the bark of the cuttings from the contaminated location, $\mathrm{Cd}, \mathrm{Zn}$ and $\mathrm{Mn}$ concentrations were 10-, 2- and 6-times higher, respectively, than for the cuttings from the uncontaminated location (Table 5). Four weeks after planting, 100\% of the 32 cuttings from the uncontaminated location had shoots, while only $25 \%$ of the cuttings from the contaminated locations had shoots. That number increased to $69 \%$ over the next four weeks and then remained steady for the last eight weeks of observation. These data indicate toxicity for the cuttings from the contaminated location. Uptake of $\mathrm{Cd}, \mathrm{Zn}$ and $\mathrm{Mn}$ in the shoots was higher for the cuttings from the dredged sediment landfill that were grown on the soil from the same location (Figure 5).

To assess whether net uptake from the soil took place, the amount of $\mathrm{Cd}, \mathrm{Zn}$ and $\mathrm{Mn}$ in the sampled cuttings 16 weeks after planting (i.e., the sum of the metal content in the bark, wood and shoot) were compared with the initial amount of these elements in the cutting at the onset of the experiment. This made it possible to discern whether metal concentrations in shoots at the end of the experiment were caused by metal translocation from the cuttings (no net uptake in the plants) or by uptake from the soil after shoot development. For Mn, no significant difference was observed between the initial amount of $\mathrm{Mn}$ in the cutting and the total amount of $\mathrm{Mn}$ in the shoot cutting, 16 weeks after planting (Figure 5). This indicates that the most important pathway for Mn in the shoots was translocation from the cutting to the shoots. The amount of $\mathrm{Zn}$ in the cuttings and shoots at the end of the greenhouse trial was 
significantly higher than the initial amount of $\mathrm{Zn}$ in the cuttings, indicating the relevance of $\mathrm{Zn}$ uptake from soil and $\mathrm{Zn}$ translocation from bark to shoot. For the cuttings with low and high metal load, 15\% and $25 \%$ of the $\mathrm{Zn}$, respectively, was taken up from the soil at 16 weeks after planting. The amount of $\mathrm{Cd}$ in the cuttings and shoots at the end of the greenhouse trial was significantly higher than the initial amount of $\mathrm{Cd}$ in the cuttings for contaminated soil, but not for the uncontaminated soil. This indicates that net $\mathrm{Cd}$ uptake from soil and $\mathrm{Cd}$ translocation from bark to shoot are relevant processes for the contaminated soil only. For the cuttings grown on the contaminated soil, only $14 \%$ of the Cd was taken up from the soil 16 weeks after planting.
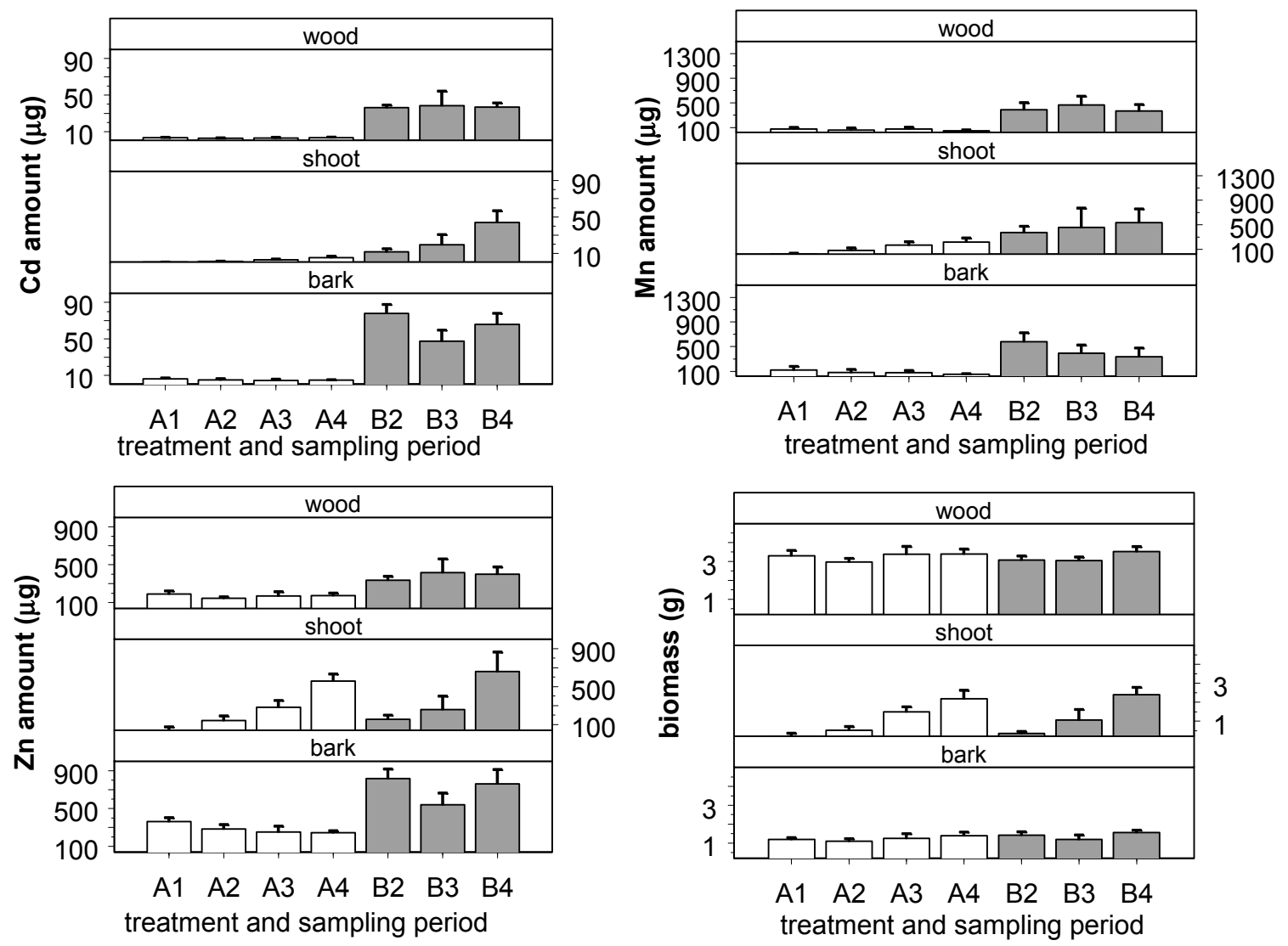

Figure 5. Biomass (expressed on a dry weight basis) and amount of $\mathrm{Cd}, \mathrm{Mn}$ and $\mathrm{Zn}$ in wood, shoot and bark per cutting of two origins of willow cuttings (A, cuttings from an uncontaminated location; B, cuttings from a contaminated location) sampled after (1) 4, (2) 8, (3) 12 and (4) 16 weeks growing in the corresponding soil types of the location. Values are the averages of four replicates per treatment per sampling event (error bars indicate the standard deviation for four replicates). 
Table 4. Properties of the uncontaminated (from Plot 0 ) and contaminated (from Plot 3 ) soil used in the first and second greenhouse trial. Values are the averages for four replicates with the standard deviation in brackets.

\begin{tabular}{|c|c|c|c|c|c|c|c|c|c|c|c|c|c|c|c|}
\hline Plot & $\mathbf{P}$ & $\mathrm{Ca}$ & $\mathbf{S}$ & Cd & $\mathbf{C u}$ & Mn & $\mathrm{Cr}$ & $\mathbf{P b}$ & $\mathbf{N i}$ & $\mathbf{Z n}$ & As & $\mathrm{CaCO}_{3}$ & TOC & $\mathrm{pH}_{\mathrm{H} 2 \mathrm{O}}$ & EC \\
\hline & \multicolumn{3}{|c|}{ g/kg dry soil } & \multicolumn{8}{|c|}{$\mathrm{mg} / \mathrm{kg}$ dry soil } & \multicolumn{2}{|c|}{$\%$} & $(-)$ & $\mu \mathrm{S} / \mathrm{cm}$ \\
\hline 0 & $0.47(0.05)$ & $16.1(5.0)$ & $0.39(0.09)$ & $0.5(0.1)$ & $13.4(1.7)$ & $724(116)$ & $60.3(7.6)$ & $21.2(4.5)$ & $23(3)$ & $92.7(7)$ & $11.4(1.7)$ & $4.7(1.5)$ & $2.5(1.0)$ & $7.7(0.1)$ & $189(20)$ \\
\hline 3 & $4.85(0.07)$ & $55.6(1.6)$ & $1.49(0.02)$ & $13.4(0.2)$ & $131(3)$ & 777 (18) & $461(12)$ & $127(2)$ & $35(1)$ & $1036(36)$ & $15(0.2)$ & $12.2(0.8)$ & $4.6(0.3)$ & $7.4(0.1)$ & $222(7)$ \\
\hline
\end{tabular}

Table 5. Concentrations of $\mathrm{Cd}, \mathrm{Zn}$ and $\mathrm{Mn}$ in the bark and wood of cuttings of the experiment on: (1) the translocation of metals from bark to shoot shortly after budburst; (2) metal translocation from cuttings to shoots versus metal uptake from soil; and (3) the experiment on the budburst of willow cuttings with increasing concentrations of $\mathrm{Mn}$ and $\mathrm{Cd}$ in the bark. Stem cuttings $\mathrm{C} 1$ to $\mathrm{C} 8$ were ranked from lowest to highest $\mathrm{Cd}$ concentration in the bark. Values are the averages of four replicates per type of cutting with standard deviation in brackets. The cuttings were collected at eight locations in the alluvial plain of the rivers Lys and Scheldt, i.e., at 3 plots on the dredged sediment landfill site, at 1 plot on the reference location and at 4 other locations (A, cuttings from an uncontaminated location; B, cuttings from a contaminated location; C, cuttings from 8 locations; $\mathrm{P}$, plot on the dredged sediment landfill or the reference location; DM, dry matter).

\begin{tabular}{|c|c|c|c|c|c|c|c|c|c|c|c|}
\hline $\mathrm{Cu}$ & ing Origin & $\mathbf{A}$ & B & C1 & $\mathrm{C2}$ & $\mathbf{C 3}$ & $\mathrm{C4}$ & $\mathrm{C5}$ & C6 & $\mathrm{C7}$ & $\mathrm{C8}$ \\
\hline & Plot & P0 & $\mathbf{P 3}$ & $\mathbf{P 0}$ & & $\mathbf{P 3}$ & & & $\mathbf{P 3}$ & $\mathbf{P 2}$ & \\
\hline & Trial & 1 & 1 & 2,3 & 3 & 2,3 & 3 & 3 & 3 & 3 & 3 \\
\hline \multicolumn{12}{|c|}{ Concentration in the Bark } \\
\hline $\mathbf{C d}$ & $\mathrm{mg} / \mathrm{kg} \mathrm{DM}$ & $5.8(0.4)$ & $55.3(6.8)$ & $3.9(0.5)$ & $20.7(7.0)$ & $25.6(4)$ & $32.9(2.2)$ & $41.0(4.0)$ & $50.7(6.2)$ & $50.8(2.7)$ & $67.1(6.8)$ \\
\hline $\mathbf{Z n}$ & $\mathrm{mg} / \mathrm{kg} \mathrm{DM}$ & $326(5)$ & $621(31)$ & $247(23)$ & $444(55)$ & $407(34)$ & $495(50)$ & $493(56)$ & $631(57)$ & $660(27)$ & $658(61)$ \\
\hline Mn & $\mathrm{mg} / \mathrm{kg} \mathrm{DM}$ & $93(15)$ & $524(143)$ & $135(26)$ & $133(7)$ & $524(124)$ & $38(2)$ & $73(11)$ & $424(49)$ & $402(159)$ & $50(7)$ \\
\hline \multicolumn{12}{|c|}{ Concentration in the Wood } \\
\hline Cd & $\mathrm{mg} / \mathrm{kg} \mathrm{DM}$ & $1.4(0.3)$ & $13.3(1.3)$ & $1.2(0.2)$ & $5.4(1.8)$ & $6.7(1.1)$ & $8.5(1.2)$ & $10.5(0.9)$ & $14.0(4.0)$ & $17.4(2.2)$ & $16.8(0.9)$ \\
\hline $\mathbf{Z n}$ & $\mathrm{mg} / \mathrm{kg} \mathrm{DM}$ & $95(26)$ & $134(6)$ & $70(9)$ & $116(20)$ & $99(12)$ & $125(21)$ & $126(15)$ & $158(38)$ & $238(39)$ & $149(13)$ \\
\hline Mn & $\mathrm{mg} / \mathrm{kg} \mathrm{DM}$ & $39(18)$ & $173(43)$ & $46(11)$ & $34(2)$ & $181(42)$ & $12(1)$ & $24(4)$ & $147(71)$ & $132(56)$ & $14(2)$ \\
\hline
\end{tabular}




\subsection{Metal Translocation from Cuttings to Shoots versus Metal Uptake from Soil}

The effect of two factors on metal uptake in wood, bark and shoot was tested in Greenhouse Experiment 2. The first factor was the effect of soil type (contaminated versus uncontaminated), and the second was the initial metal load of the cutting (cuttings with high concentrations in the bark versus cuttings with low concentrations). With this experiment, we aimed to differentiate the effect of the uptake of $\mathrm{Cd}, \mathrm{Zn}$ and $\mathrm{Mn}$ from the soil and translocation of these elements from the bark and wood to the developing shoots. Ten weeks after planting, $95 \%$ of the cuttings from the uncontaminated location grown on uncontaminated soil had shoots, in contrast with $100 \%$ of the same cuttings grown on contaminated soil. Of the cuttings taken from contaminated locations, $75 \%$ of them had shoots when grown on uncontaminated soil, while only $30 \%$ had shoots when grown on contaminated soil. These data indicate toxicity for the cuttings from the contaminated location, which seems to be higher when those cuttings were grown on the contaminated soil.
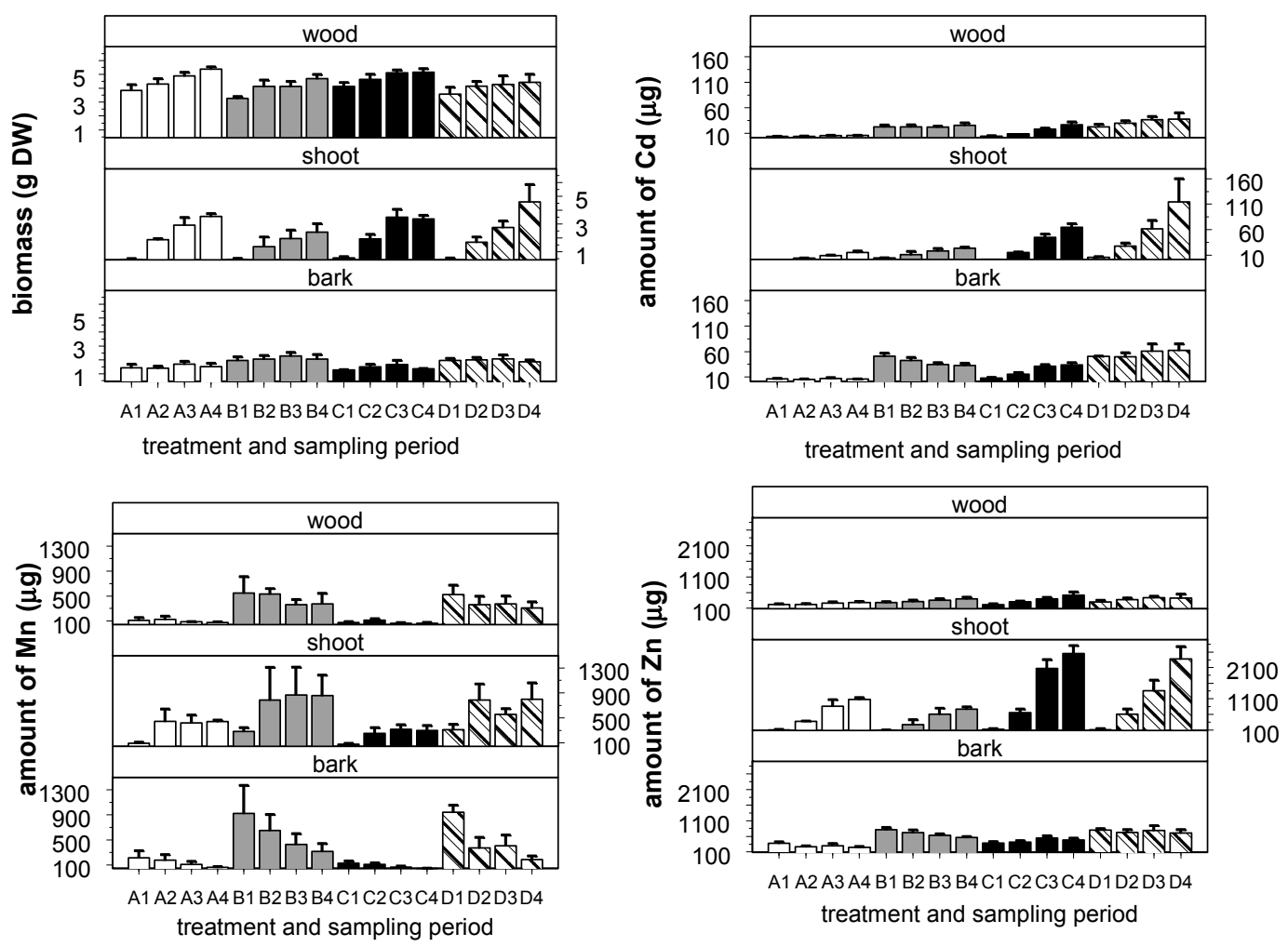

Figure 6. Biomass and amount of $\mathrm{Cd}, \mathrm{Mn}$ and $\mathrm{Zn}$ in wood, shoot and bark per cutting of two origins of willow cuttings (A and $\mathrm{C}$, cuttings from an uncontaminated location; $\mathrm{B}$ and D, cuttings from a contaminated location) sampled after (1) 10 , (2) 15 , (3) 20 and (4) 25 weeks growing in two soil types. Values are the averages of four replicates per treatment per sampling event (error bars indicate the standard deviation for four replicates; DW, dry weight).

Uptake patterns are element specific (Figure 6). Cd uptake in the shoots was clearly illustrated for objects with cuttings from the contaminated site and/or soil from the contaminated site. In the case where cuttings with a high metal load were grown on the uncontaminated soil, this resulted in decreasing amounts of $\mathrm{Cd}$ in the bark (Cd translocation from bark to shoot). When cuttings with a low metal load 
were grown on the contaminated soil, this resulted in increasing amounts of $\mathrm{Cd}$ in the bark, indicating Cd uptake from the soil. Cd uptake in the shoot thus appears to be the result of both uptake from the soil, as well as translocation from the bark to the shoot.

Mn uptake in the shoots was clearly illustrated for all objects. They all had decreasing amounts of $\mathrm{Mn}$ in the bark (Mn translocation from bark to shoot). Zn uptake in the shoots was also clearly observed for all objects, but the decrease in the amount of $\mathrm{Zn}$ in the bark was clearly less marked than for Mn and somewhat less than for Cd (Figure 6). Zn uptake in the shoot thus appears to be mainly the result of uptake from the soil. The amount of $\mathrm{Zn}$ in the shoots increased strongly during the last two sampling events, resulting in higher $\mathrm{Zn}$ amounts in the shoots in the second plot trial (Figure 6) than at the end of the first trial (Figure 5). The increase in the amount of Mn in the shoots was faster than for Cd and $\mathrm{Zn}$. This confirmed the importance of Mn translocation from bark to shoots, as this is a faster process than uptake from soil by the initially unrooted cuttings.

In the bark, the total amount of Mn decreased during the trial for all combinations of cuttings and soils. The total amount of $\mathrm{Cd}$ in the bark decreased for the cuttings with high initial Cd concentrations growing on the contaminated soil, but increased for the cuttings with low initial Cd concentrations growing on the contaminated soil (Figure 6). From the comparison of the total amount of Mn in the cuttings before and after shoot development, no net uptake for Mn was detected: the amount of Mn in the cuttings with shoots was not significantly higher than the initial amount of $\mathrm{Mn}$ in the cuttings before the trial. In contrast, for $\mathrm{Cd}$ and $\mathrm{Zn}$, net uptake during the shoot formation was observed for both types of cuttings grown on the contaminated soil (significantly higher amount of $\mathrm{Cd}$ and $\mathrm{Zn}$ at the end of the trial than in the cuttings before the trial), but not for the cuttings grown on the uncontaminated soil.

\subsection{Budburst of Willow Cuttings}

The aim of Greenhouse Experiment 3 was to assess the effect of different loads of $\mathrm{Cd}, \mathrm{Zn}$ and $\mathrm{Mn}$ in bark on survival, budburst and shoot growth of willow cuttings. The $\mathrm{Cd}, \mathrm{Zn}$ and $\mathrm{Mn}$ concentrations in the bark and wood varied widely among the tested groups of cuttings taken from eight locations (Table 5). The cuttings from locations $\mathrm{C} 3$ (Cutting 3), C6 and C7 were collected at the dredged sediment landfill monitored in this study, i.e., Plot 3 (C3 and C6) and Plot 2 (C7). The cuttings from location $\mathrm{C} 1$ were collected at the landfill site containing non-contaminated infrastructure spoil, i.e., Plot 0 . The other four groups of cuttings were collected on locations on alluvial soils along the Lys and Scheldt rivers. Cuttings from these locations were ranked in Table 5 according to increasing Cd concentrations in the bark. This largely coincides with the sequence for $\mathrm{Zn}$ concentrations in the bark, since we observed a strong positive correlation between $\mathrm{Cd}$ and $\mathrm{Zn}(R=0.95, p<0.05)$ in the bark in these cuttings.

C3 and C6 showed delayed budburst and less shoot formation (Figure 7). These cuttings had the highest Mn concentrations in the bark (Table 5) and in the shoots (Figure 8). The delayed budburst was also observed for $\mathrm{C} 7$, but the effect was smaller. For $\mathrm{Cd}$, the highest shoot concentrations five weeks after planting were measured for the cuttings with the highest $\mathrm{Cd}$ concentrations in the bark (Figure 8). We found decreasing concentrations for $\mathrm{Cd}$ for seven of the eight groups of cuttings, indicating dilution by growth, i.e., a faster increase of shoot biomass than the amount of Cd taken up in the shoots, resulting in decreasing concentrations in the shoots (Figure 8). This effect was also observed for three of the eight groups of cuttings for Mn. This may indicate very high tissue concentrations of these elements in the 
shoots at budburst, resulting in direct toxicity or indirect deficiencies due to the high Mn concentrations. We found a strongly negative correlation between the number of cuttings with shoots six weeks after planting and the initial Mn concentration in the bark $(R=-0.86, p<0.05)$ or the Mn concentration in the shoots 10 weeks after planting $(R=-0.94, p<0.05)$. The uptake of $\mathrm{Cd}, \mathrm{Zn}$ and $\mathrm{Mn}$ from the potting soil mix is expected to be low; this is confirmed by the observed dilution by growth in the shoots, with the translocation from the bark to the shoots as the main process for $\mathrm{Cd}, \mathrm{Zn}$ and $\mathrm{Mn}$ uptake in shoots.

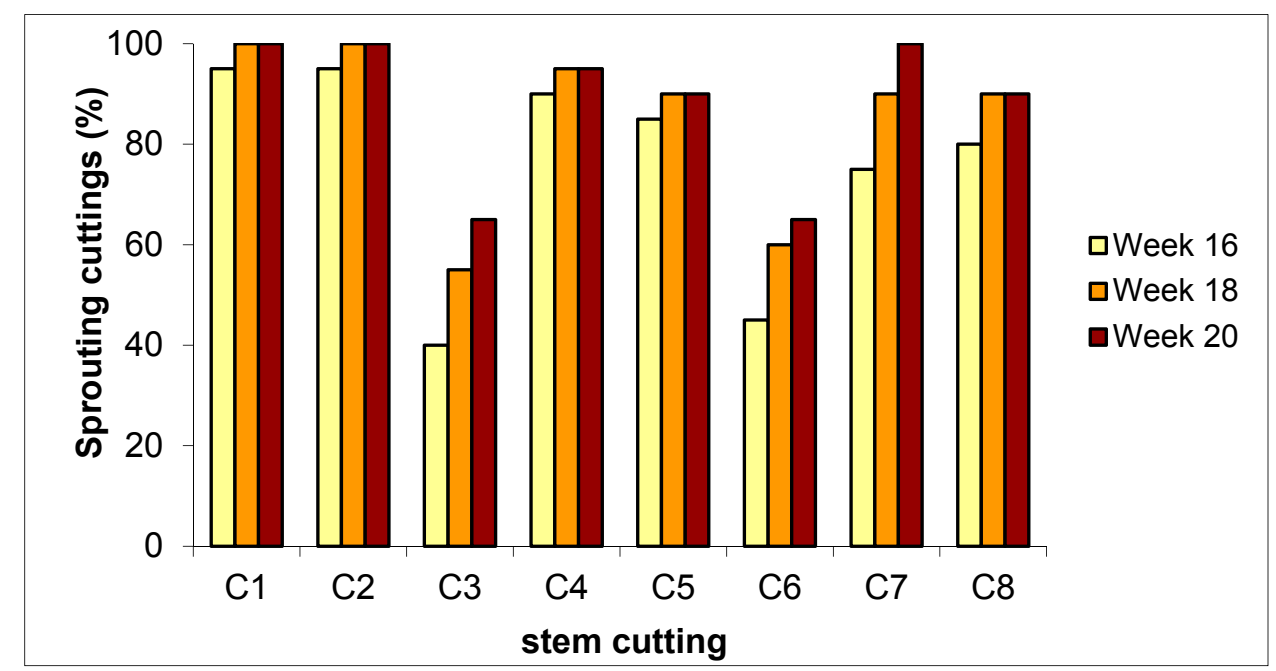

Figure 7. Percentage of sprouted cuttings in a greenhouse trial for Salix cinerea stem cuttings with different concentrations of $\mathrm{Cd}, \mathrm{Zn}$ and $\mathrm{Mn}$ counted 6, 8 and 10 weeks after planting (stem cutting $\mathrm{C} 1$ to $\mathrm{C} 8$ : from lowest to highest $\mathrm{Cd}$ concentration in the bark; see Table 5; cuttings $(\mathrm{C})$ collected at eight different locations in the alluvial plain of the rivers Lys and Scheldt). In total, 20 cuttings were grown per origin.

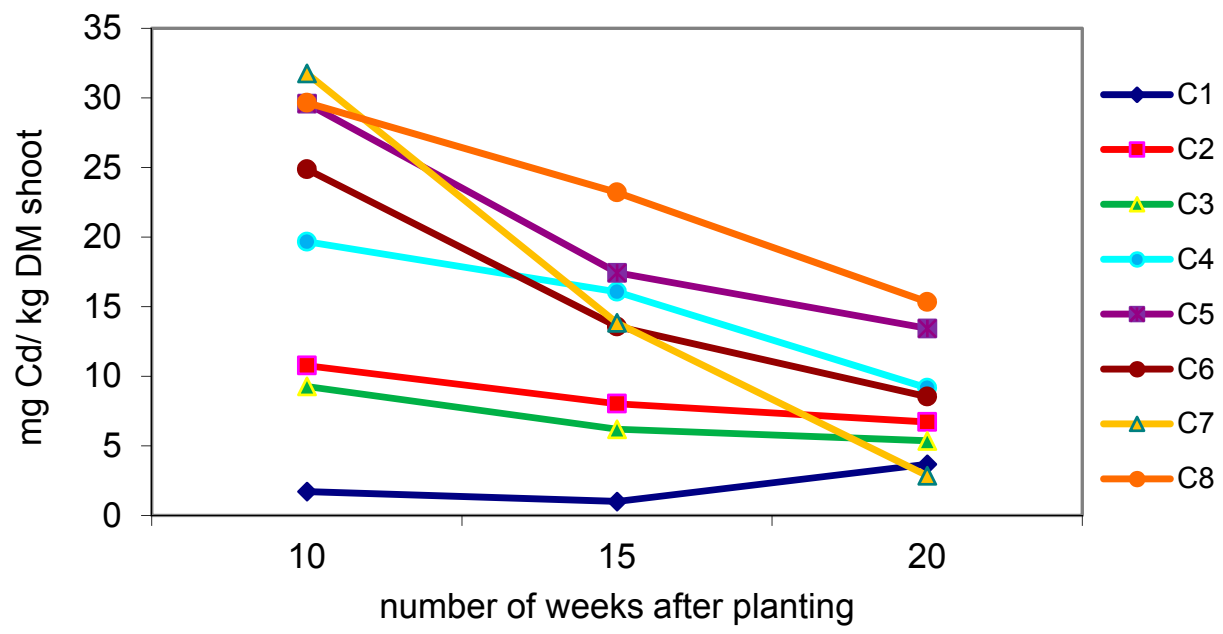

(a)

Figure 8. Cont. 


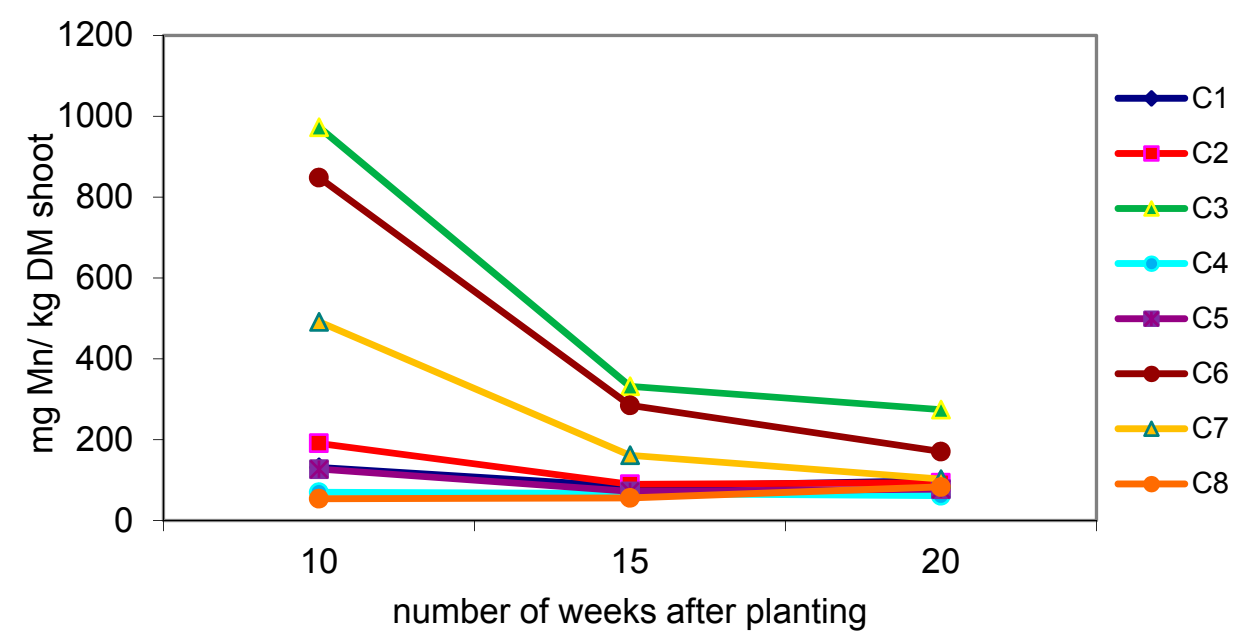

(b)

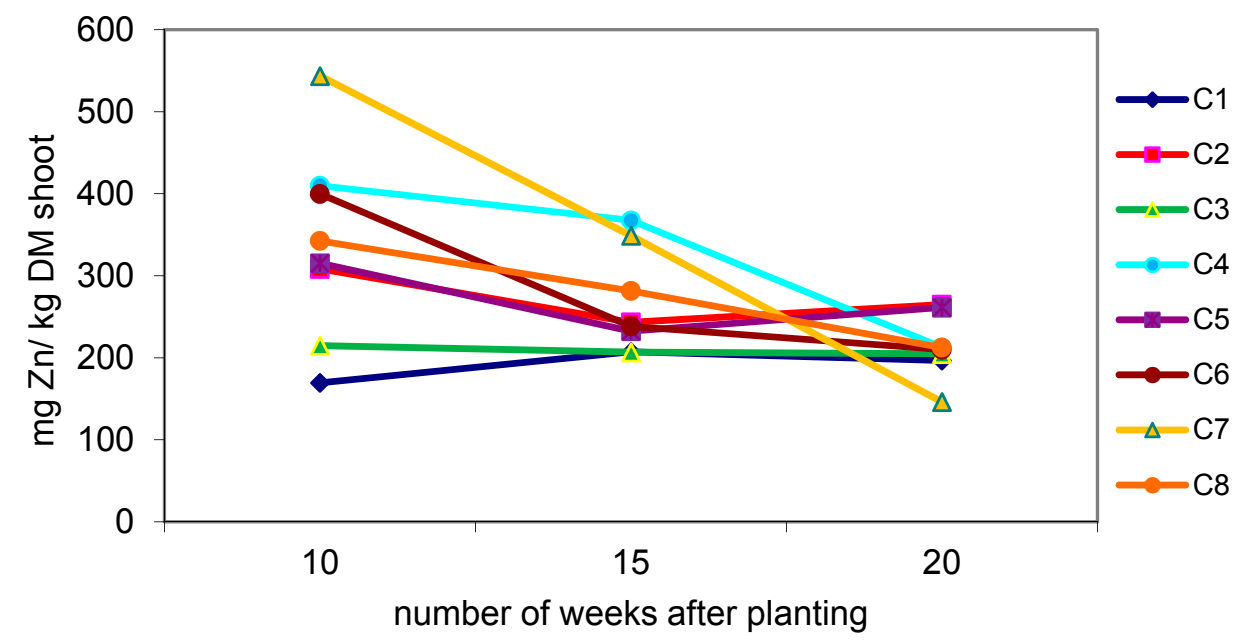

(c)

Figure 8. Concentrations of (a) $\mathrm{Cd},(\mathbf{b}) \mathrm{Mn}$ and (c) $\mathrm{Zn}$ in the shoots 10, 15 and 20 weeks after planting in a greenhouse trial for Salix cinerea stem cuttings (C) with different concentrations of $\mathrm{Cd}, \mathrm{Zn}$ and $\mathrm{Mn}$ (DM, dry matter).

\subsection{Discussion}

\subsubsection{Changes in the Abiotic Context Affect Vegetation}

Both the sandy part and the clay part of the dredged sediment landfill had a higher degree of contamination with heavy metals (Table 1 ) than for Plot 0 , the reference plot in this study (Table 4). During the four-year monitoring period, we observed changes in hydrology, topsoil properties and uptake of metals in Salix cinerea for the dredged sediment landfill. Hydrological changes between 2003 and 2006 were indicated by the decreasing flooding depths, the decreasing water table levels in the initially submerged plots and the higher redox values in the top soils. The period of submergence (=ponding water on the soil surface) in the winter for the initially submerged plots was shorter in 2004 in comparison with 2003 [20], and no ponding water was observed on the six selected plots during the last two years of the trial. 
The changes in hydrology resulted in drier top soils and higher redox values and indirectly resulted in changes in topsoil chemistry. The most obvious change in the topsoil was the sulfate leaching to deeper layers and the related decrease in EC, which has been observed for dredged sediments during ripening after land disposal [21,22]. The very high and variable sulfate concentrations at higher depths should be attributed to sulfide accumulation under anoxic conditions in the years after sediment disposal, followed by re-oxidation due to the more recent hydrological changes. The impact of variable sulfate to sulfide ratios on the fate and mobility of metals as affected by changes in hydrology is determined by the sulfide content, the metal content and the solubility of the different metal sulfides, as observed previously [23-25].

The calcareous sediments of the sampled dredged sediment landfill obviously had a buffer capacity that was large enough to counteract acidification during the oxidation of reduced sulfur compounds in the initially reduced sediments, as indicated by nearly neutral $\mathrm{pH}$ values (Table 1). This was also observed at other contaminated dredged sediment landfills: when comparing topsoil with the deeper soil layer at four sites, sulfate leaching from the topsoil on these contaminated sites resulted in even slightly higher $\mathrm{pH}$ values in the topsoil [24]. Although the neutral $\mathrm{pH}$ values in the topsoil of this site may have reduced some of the bioavailability of $\mathrm{Cd}$ and $\mathrm{Zn}$, the foliar, wood and bark concentrations for $\mathrm{Cd}$ and $\mathrm{Zn}$ in the willows were still much higher than those in the reference plot.

Observations from a previous study, characterized by an evolution towards shorter periods of submerged soils and decreasing water table levels, revealed trends of increased availability of $\mathrm{Cd}$ and $\mathrm{Zn}$, but decreasing $\mathrm{Mn}$ and Fe availability in the soil [26], resulting in higher $\mathrm{Cd}$ and $\mathrm{Zn}$, but lower Mn uptake in willows [13]. The effect of submergence on the availability of $\mathrm{Cd}, \mathrm{Zn}$ and $\mathrm{Mn}$ is dependent on the sulfate and sulfide content of the soil, however [23-25]. In general, the increased availability for Cd and $\mathrm{Zn}$ is confirmed by monitoring the foliar concentration. However, we also observed increasing $\mathrm{Mn}$ concentrations in leaves, stems and bark during the four-year period (Figures 3 and 4). The increasing plant uptake indicates that $\mathrm{Mn}$ availability for the willows is increasing despite the drop in the water table. A possible explanation is that fine plant roots are mainly active at the anaerobic/aerobic interface, a location where Mn availability may be higher, affected by the related transition of sulfides to sulfates. In this transition zone, further oxidation may result in a reduction of Mn availability through precipitation of Mn-oxides [23]. As the water table drops, the sediments settle further and are compacted during drying and oxidation. These processes may cause changes in the soil structure, permeability and the related metal availability. Stephens et al. [27] reported an increase in the sulfide/sulfate ratio in an oxidizing sediment after 35 days of oxidation. They postulated that this was caused by a decrease in permeability of the sediment as it dried, thus limiting oxygen diffusion throughout the profile. Another possible explanation for the increasing Mn concentrations in the willow leaves despite the expected lower Mn availability in the soil is that Mn taken up by the willows and stored in the bark in previous years is later translocated to the leaves, while the net uptake of $\mathrm{Mn}$ is actually decreasing. The role of $\mathrm{Cd}$ and $\mathrm{Mn}$ translocation from bark to leaves in the early growing season is illustrated by the relatively high foliar concentrations for $\mathrm{Mn}$ and $\mathrm{Cd}$ measured already in the early growing season on the contaminated dredged sediment landfill during the field monitoring; for $\mathrm{Zn}$, this effect was less clear. Zn stored in the bark is less easily mobilized for translocation to the leaves, as was observed in the greenhouse trials (Figures 5, 6 and 8). 


\subsubsection{Translocation of Metals from Bark to Shoots and Effects on Budburst}

Although other studies measured the effect of submergence or emergence on $\mathrm{Cd}, \mathrm{Zn}$ or Mn concentrations in the leaves $[3,9,15]$, these studies did not assess metal concentrations in bark and wood or their role as the intermediate stock point for these metals in the plant. However, the amount of $\mathrm{Cd}, \mathrm{Zn}$ and $\mathrm{Mn}$ in the bark might be an important pool of the total content in the total tree biomass. For willows and poplars, higher $\mathrm{Cd}, \mathrm{Zn}$ and $\mathrm{Mn}$ concentrations in the bark than in the wood have been reported both for contaminated [28,29] and uncontaminated sites [30,31].

From the experiments with cuttings on the translocation of metals from willow bark to shoots and effects on budburst and growth, we conclude that $\mathrm{Cd}, \mathrm{Zn}$ and $\mathrm{Mn}$ behave in a specific way, and especially, the high Mn concentrations translocated from the bark to the young shoots are directly or indirectly related to delayed budburst or fewer buds opening. Our results indicate that high $\mathrm{Mn}$ in the bark results in fewer buds opening rather than high $\mathrm{Cd}$ or $\mathrm{Zn}$ concentrations; cuttings from other locations had equal or higher $\mathrm{Cd}$ and $\mathrm{Zn}$ concentrations (Table 5) without the same negative effect on budburst and shoot growth (Figure 7). However, we cannot determine the specific process for this effect on budburst. Mn toxicity in plants is often the result of complex interactions with other nutrients [18], i.e., competitive interference and consequent deficiency of essential nutrients, such as $\mathrm{Ca}, \mathrm{Cu}, \mathrm{Mg}$ and Fe [16,17], or interactions with environmental factors [18]. Interaction between elements should thus be considered for proper interpretation of the observed signs of toxicity. Barrick and Noble [9] proposed that high Fe:Mn ratios in leaves were indicative of toxicity in tree species due to long-term waterlogging, while Thomas and Sprenger [16] reported inhibition of Fe uptake due to excess Mn, resulting in very low Fe:Mn ratios.

Comparison with the initial $\mathrm{Cd}, \mathrm{Mn}$ and $\mathrm{Zn}$ contents in the cuttings revealed that $\mathrm{Cd}$ and $\mathrm{Zn}$ content clearly increased in the aboveground plant parts during the greenhouse experiments, while this was not the case for Mn. Mn was mainly translocated from the bark to the shoot during the first weeks of the trials, and no net increase of $\mathrm{Mn}$ in the aboveground plant parts was observed. $\mathrm{Cd}$ and $\mathrm{Zn}$ were taken up from the soil. Mn was taken up in relatively smaller amounts from the soil, probably due to the oxidized soil conditions in all treatments. For the treatments with the contaminated soils, Zn uptake in shoots was higher in the second than in the first greenhouse trial, as Zn uptake in this compartment only clearly increased after 15 to 20 weeks. This may indicate preferential $\mathrm{Zn}$ accumulation in roots before $\mathrm{Zn}$ is translocated to the shoots. Uptake from the soil may interact with the translocation of elements from the stem cutting to shoots. For a contaminated dredged sediment-derived soil, Vandecasteele et al. [13] observed that the translocation from stem cutting to shoots was lowest for $\mathrm{Cd}$, intermediate for $\mathrm{Zn}$ and highest for Mn. In the present study we observed that the bark is an important source for Cd in the leaves in the early growing season. Unterbrunner et al. [29] reported a higher relative importance of bark concentrations versus leaf concentrations for $\mathrm{Cd}$ than for $\mathrm{Zn}$, both in Populus tremula and Salix caprea. $\mathrm{Cd}, \mathrm{Mn}$ and $\mathrm{Zn}$ were higher in the bark than in the rest of the willow leader for mountain and Geyer willow cuttings grown on amended mine tailings for four months in a greenhouse study [11], indicating that even in young plants, the bark may contain higher concentrations than other plant parts. $\mathrm{Cd}, \mathrm{Mn}$ and, to a lesser extent, $\mathrm{Zn}$ stored in the bark are not immobilized in this plant compartment in an irreversible way. At the end of the growing season, we did not observe retranslocation of these elements in the leaves to other plant parts before leaf drop. However, plants may have strategies to cope with high metal 
concentrations in plant parts. Vollenweider et al. [32] reported evidence for Cd sequestration in willows exposed to high $\mathrm{Cd}$ concentrations as a process for controlled allocation within the leaf. This strategy for avoiding toxicity for sensitive parts of the leaf coincided with adaptations in the cell physiology. Besides these mechanisms of $\mathrm{Cd}$ storage and detoxification, Vollenweider et al. [32] observed that reallocation of $\mathrm{Cd}$ within the leaves occurred in older leaves.

\subsubsection{Effects of Mn on Vegetation: Ecological or Ecotoxicological Process}

Ecosystems may develop on contaminated sediment-derived soils, but higher metal availability in leaves and forest floor litter [20,33] may result in ecological risks [6]. In previous research, reflooding the emerged sediments was proposed as a good option to decrease the metal availability [14,34]. The vegetation that develops on contaminated sites is the result of interacting factors. Changes in hydrology will affect the vegetation succession: when $S$. cinerea disappear due to toxicity or deficiency related to the hydrological changes towards more upland conditions, other vegetation may develop. Reed might be another typical species that diminishes during this vegetation transition. In contrast to $S$. cinerea, Phragmites australis may accumulate low metal concentrations, but the reed litter may indirectly affect the metal availability in the soil [35].

In relatively stable or slowly changing ecosystems, tolerance for $\mathrm{Mn}$ may determine or affect the vegetation succession, but habitat may affect the tolerance, as well. Populus cathayana cuttings exposed to Hoagland's solutions with high Mn concentrations suffered from stress, but differences in susceptibility for Mn stress between the wet climate and dry climate population were reported [36]. According to the authors, this difference was due to cross-tolerance between $\mathrm{Mn}$ and drought resistance in poplars, being higher in the dry climate population [36]. Different responses to stress caused by Mn were thus found between two contrasting populations [36], indicating a population effect on tolerance for Mn toxicity. Even for willow plantations, the biomass production may be reduced by high Mn concentrations in wet soils [5]. Differences between species in relation to Mn may indicate differences in habitat adaptation, and this adaptation can explain the high Mn toxicity thresholds (i.e., high Mn tolerance) and high $\mathrm{Mn}$ uptake in some willow species [17].

When abiotic factors of the ecosystem change over a relatively short period, as is the case in this study, the effects may become more obvious. Results from the field monitoring and the greenhouse trials provide insight into potential endpoints for ecotoxicity. The results point to the importance of high $\mathrm{Mn}$ concentrations in the bark affecting the budburst and the foliar concentrations. Budburst phenology was an indicator in other studies on flooding and/or effects of metal pollution [8,37]. However, budburst may be affected by other factors, as well. Kozlov et al. [37] reported delayed budburst in a greenhouse experiment with white birch seedlings on contaminated soils, but observed advanced budburst for white birch growing in the area of a nickel-copper smelter. The reason for the latter observations seems to be an effect of microclimatic differences between the studied sites, which was not the case in the greenhouse trial [38].

Although the high Mn concentrations in the bark in our study reflect high Mn availability in the soil, at least in some layers in the soil and during some periods, they cannot be directly linked to total Mn concentrations in the top soil. The soil hydrology, which has an important effect on metal availability, is subject to seasonal trends. At the very least, these results warrant for cautious interpretation of short-term ecotoxicity tests with plants, as we measured effects in the greenhouse trial due to 
accumulation of $\mathrm{Mn}$ in the bark over longer periods. The toxicity related to these accumulation effects can only be detected in the medium term. We can expect toxicity on contaminated sites, but here, it is caused by Mn and not by any of the heavy metals considered as the "real" pollutants on this site. Cd and $\mathrm{Zn}$ are the main elements in the pollution assessment of the studied site, but only Mn could be directly or indirectly related to symptoms of toxicity. In contrast to $\mathrm{Cd}$ and $\mathrm{Zn}, \mathrm{Mn}$ is not categorized as a pollutant. We could not determine whether high $\mathrm{Cd}$ and $\mathrm{Zn}$ concentrations have an additional effect on the budburst and growth of the willows. A similar effect on budburst was observed for the cuttings with high Mn concentrations in the bark grown in the potting soil (greenhouse Experiment 3,40\% budburst after 16 weeks) and in the contaminated soil (greenhouse Experiment 2, 30\% budburst after 10 weeks), but a higher degree of budburst was observed in the uncontaminated soil (greenhouse Experiment 2, 75\% budburst after 10 weeks), indicating possible interaction effects.

\subsubsection{Experiments with Willow Cuttings}

Willow cuttings collected from contaminated locations may differ in growth, metal uptake and tolerance from cuttings from contaminated locations. This could be due to acclimation to metal stress [38] and the effect of metals already included in the bark and the wood of the cuttings released through translocation (present study). Mleczek et al. [39] reported an effect of age of the cuttings on metal uptake. Willow cuttings were exposed directly to contaminated and uncontaminated soils. We used unrooted cuttings, which may affect the results of the trials, as unrooted cuttings may be exposed to higher stress, as both roots and shoots have to be developed. Bourret et al. [3] concluded after four growing seasons that pre-rooted cuttings of mountain willow had a consistently higher survival rate than staked cuttings and that the root status affected Cd uptake in the plants. A higher survival rate for rooted versus unrooted willow cuttings in degraded montane riparian areas was also reported by Gage and Cooper [2]. Unrooted cuttings may thus represent the worst-case scenario, i.e., a scenario resulting in higher mortality of the cuttings with high Mn concentrations in the bark.

\section{Experimental Section}

The study site was a 13.3-ha dredged sediment landfill in Semmerzake (Belgium), near Ghent. It was landfilled between 1992 and 1995 using sediments dredged from the Upper Scheldt River. The site had the typical texture gradient observed at several landfill sites for dredged sediments, with a sandy part closest to the dredged sediment discharge and sedimentation of materials with a higher clay content in the rest of the landfill site. Until 2003, the site could generally be characterized as a wetland with stagnant water from late autumn to mid-spring, with a large pond in the southern part of the site [20]. However, the site is gradually drying out as indicated by the decrease in the surface of the pond, decreased periods of submersion and longer periods with oxic soil conditions in subsequent years [20].

\subsection{Monitoring of Soil Properties and Groundwater Levels}

For general characterization of the topsoil of the dredged sediment landfill site, the 0-30 soil horizon was sampled in July 2003, on the 23 points of a regular grid using a stainless steel gouge auger. Each sample was a composite of 4 subsamples, taken in a circle of $1 \mathrm{~m}$ in diameter around the sampling point. 
In July 2005, these points were resampled for determination of total S, sulfate concentration and electrical conductivity (EC). In fall 2005 and 2006, the soil profile was sampled to a depth of $100 \mathrm{~cm}$ in $10-\mathrm{cm}$ intervals in a part of the site that mostly emerged during the growing season of 2003 and 2004 (referred to below as Plot 3). Groundwater dynamics were monitored in a piezometer network consisting of 23 piezometers at an average total depth of $2 \mathrm{~m}$ and a filter length of $0.5 \mathrm{~m}$. Water levels were measured every fortnight using a Schlumberger Water Services Diver ${ }^{\circledR}$ water level meter with an audible and visible alarm that is activated when the probe makes contact with water. Piezometers are not exactly located in the vegetation plots. We selected the closest piezometer in the same vegetation type to represent the hydrological conditions of each of the plots.

\subsection{Monitoring of Metal Concentrations in Vegetation}

Vegetation was sampled at two sites: (1) the contaminated dredged sediment landfill (6 plots); and (2) a landfill site containing non-contaminated infrastructure spoil (reference plot). For the purposes of this work, a plot is defined as an approximately $10 \times 10 \mathrm{~m}$ area with relatively homogeneous soil properties. For the monitoring of metal concentrations in vegetation, we selected six plots (Plots 1-6) in the dredged sediment landfill site. These plots represent a range of hydrological regimes, as indicated by varying water levels and redox potentials [20]. We included an additional reference plot (Plot 0) on a nearby landfill site containing non-contaminated infrastructure spoil. Based on hydrology, plots could clearly be separated into 2 groups: Plots 1, 2 and 3 had a similar hydrological regime in 2003 and the next three years and were mostly emerged during the growing season, while Plots 4, 5 and 6 were initially submerged in 2003, but were markedly drier from 2004 on [20]. Plot 1 was located in a more elevated part of the study area (closer to the discharge), which contains sediments with a higher sand content. Plots 2-6 were located in the part where sediments with a higher clay content had settled. To account for the variability associated with sampling, four different Salix cinerea L. shrubs of approximately the same age and diameter were sampled within a plot. Foliar samples were taken every three weeks between Week 18 and Week 42 (i.e., week number during the year) during the growing season of 2003 until 2006. Approximately $500 \mathrm{~cm}^{3}$ of leaf samples were collected for each shrub at each sampling occasion. Four individual shrubs per plot were selected, and for each shrub, the leaves of four branches from different heights and positions in the crown were sampled by means of an extension crosscut saw. Leaves were not washed prior to analysis. For monitoring the $\mathrm{Cd}, \mathrm{Zn}$ and $\mathrm{Mn}$ concentrations in the stems, two willow cuttings from two-year-old dormant stems of each shrub were collected in Week 49 during each of the 4 years.

\subsection{Greenhouse Experiment 1: Metal Translocation from Cuttings to Shoots during the First Weeks of} the Growing Season

In this greenhouse experiment, we compared the distribution of $\mathrm{Cd}, \mathrm{Zn}$ and $\mathrm{Mn}$ across the bark, wood and shoots of the plants in the first weeks after planting cuttings. Two situations were monitored: (A) cuttings with low bark concentrations grown in uncontaminated soil; and (B) cuttings with high bark concentrations grown in contaminated soil. Each type of cutting was grown in the soil in which its mother plant had grown. Soil and stem cuttings were collected in February 2005, from 2 plots: Plot 0 (contaminated plot, cuttings with low $\mathrm{Cd}, \mathrm{Mn}$ and $\mathrm{Zn}$ concentrations) and Plot 3 (contaminated sediment, 
cuttings with high $\mathrm{Cd}, \mathrm{Mn}$ and $\mathrm{Zn}$ concentrations). The $0-15-\mathrm{cm}$ soil horizon was sampled on Plot 0 and the $0-30-\mathrm{cm}$ soil horizon on Plot 3 . Soil material was intensively mixed and homogenized, sieved with a $10-\mathrm{mm}$ sieve, and any stones, plastics, twigs and branches were removed. Willow cuttings were collected from two-year-old dormant stems from the plots described above, were wrapped in plastic bags to prevent desiccation and stored as $1-\mathrm{m}$ stems for 1 week at $4{ }^{\circ} \mathrm{C}$.

In total, 64 containers (32 containers per combination of cutting origin and the corresponding soil type) were used in the trial. Willow cuttings were $20 \mathrm{~cm}$ long and were planted in $13 \times 13 \times 13 \mathrm{~cm}$ containers with $1 \mathrm{~kg}$ wet soil. Two cuttings with a total fresh weight between 15.6 and $18.0 \mathrm{~g}$ were planted in each container, then placed in a greenhouse and regularly irrigated with rainwater. A dish placed under each replicate prevented the export of soil material or dissolved elements. The greenhouse experiment started in Week 10 (i.e., the second week of March 2005).

For assessing initial metal concentrations in willow cuttings, at the start of the experiment, 4 pairs of cuttings were split up into bark and wood and analyzed. The surviving cuttings of 4 replicates per treatment were harvested at 4 sampling events, i.e., 4, 8, 12 and 16 weeks after planting, respectively. Cuttings were split up into shoots, bark and wood. These compartments were dried and weighed separately as follows: shoots and roots were removed from the cuttings, and soil particles were washed from the cuttings; and then, cuttings were split up into bark and wood. For the first sampling, the shoot biomass was too low for a separate analysis per replicate, and therefore, samples were mixed together to form one sample.

\subsection{Greenhouse Experiment 2: Metal Translocation from Cuttings to Shoots versus Metal Uptake from Soil}

The effect of two factors on metal uptake in wood, bark and shoot was tested in this experiment. The first factor was the effect of soil type (contaminated versus uncontaminated) and the second was the initial metal load of the cutting (cuttings with high concentrations in the bark versus cuttings with low concentrations). Combining two levels of soil contamination with two levels of metal loads in the bark of the cuttings resulted in an experiment with 4 treatments. With this experiment, we aimed to differentiate the effect of the uptake of $\mathrm{Cd}, \mathrm{Zn}$ and $\mathrm{Mn}$ from the soil and translocation of these elements from the bark and wood to the developing shoots. The uptake of metals was monitored during 25 weeks after planting, i.e., for a longer period than in greenhouse Experiment 1.

Soil and stem cuttings were collected in February 2006, from 2 plots: Plot 0 (contaminated plot, cuttings with low $\mathrm{Cd}, \mathrm{Mn}$ and $\mathrm{Zn}$ concentrations) and Plot 3 (contaminated sediment, cuttings with high $\mathrm{Cd}, \mathrm{Mn}$ and $\mathrm{Zn}$ concentrations). The $0-15-\mathrm{cm}$ soil horizon was sampled on Plot 0 and the $0-30-\mathrm{cm}$ soil horizon on Plot 3. Soil material was intensively mixed and homogenized, sieved using a 10-mm sieve, and any stones, plastics, twigs and branches were removed. Willow cuttings were collected and stored as described above.

In total, 80 containers (20 containers per combination of cutting and soil) were used in the trial. Willow cuttings were $20 \mathrm{~cm}$ long and were planted in $13 \times 13 \times 13 \mathrm{~cm}$ containers with $1 \mathrm{~kg}$ wet soil. Two cuttings with an individual fresh weight between 10.0 and $12.0 \mathrm{~g}$ and a total fresh weight between 21.0 and $23.0 \mathrm{~g}$ were planted in each container, then placed in a greenhouse and regularly irrigated with 
rainwater. Each replicate was provided with a dish underneath to avoid the export of soil material or dissolved elements. The greenhouse experiment started in Week 10 (second week of March 2006).

The surviving cuttings of 4 replicates per treatment were harvested 10, 15, 20 and 25 weeks after planting, respectively, with the same methodology as described above; 16 of the 20 pots were sampled, while the other 4 pots were checked for budburst, shoot and root formation. For the first sampling, the shoot biomass was too low for a separate analysis per replicate; thus, samples were mixed into one sample.

\subsection{Greenhouse Experiment 3: Experiment on Budburst of Willow Cuttings}

The aim of this experiment was to assess the effect of different loads of $\mathrm{Cd}, \mathrm{Zn}$ and $\mathrm{Mn}$ in bark on survival and budburst of willow cuttings. Cuttings of $S$. cinerea were collected at 8 locations in the alluvial plain of the Lys and Scheldt rivers with variable soil contamination status, resulting in variable metal loads in bark and wood. These willows can be categorized as $S$. cinerea with a limited degree of crossing with $S$. caprea. Willow cuttings were collected and stored as described above. A $20 \mathrm{~cm}$ long cutting of each location was planted in each of the 20 containers $(5 \mathrm{~L})$ filled with a standard potting mix, thus resulting in 8 different cuttings per container. The containers were placed in a greenhouse and regularly irrigated with rainwater. Per location, 4 pairs of cuttings were split up into bark and wood and analyzed at the start of the experiment in Week 10 (second week of March 2006). The number of cuttings with shoots were counted 6, 8 and 10 weeks after planting. At each sampling event, five containers were harvested, i.e., after 10, 15 and 20 weeks after planting, respectively. The other 5 pots were checked for budburst, shoot and root formation only. Per cutting of each location, shoots, bark and wood were sampled, dried and weighed separately. For the first sampling, the shoot biomass was too low for a separate analysis per replicate, and therefore, the 5 samples for each location were mixed into one sample.

\subsection{Chemical Analyses}

Leaf, stem and root samples were dried for 7 days at $40{ }^{\circ} \mathrm{C}$, mechanically ground (Pulverisette 14, Fritsch, Idar-Oberstein, Germany) and stored in dark vials until analysis. Wood and bark samples were dried for 14 days at $40{ }^{\circ} \mathrm{C}$ and mechanically ground in a low-speed grinder (Retsch SM2000, Retsch, Haan, Germany) to avoid heating them. Total plant element concentrations were measured by a simultaneous inductively coupled plasma optical emission spectrometer (ICP-OES) (VISTA-MPX, Varian, Palo Alto, CA, USA), following digestion with $\mathrm{HNO}_{3}$ (p.a. 65\%) and $\mathrm{H}_{2} \mathrm{O}_{2}$ (ultrapure) in a 3:1 ratio using a microwave digester (Milestone $1200 \mathrm{MS}$ Mega, Shelton, CT, USA). The accuracy of the element analysis was checked using BCR 60 (aquatic plants) for $\mathrm{Cd}, \mathrm{Cu}, \mathrm{Mn}$ and $\mathrm{Zn}$ and $\mathrm{CRM} 100$ (beech leaves) for S and P.

Soil samples were dried at $40{ }^{\circ} \mathrm{C}$ until constant weight and disaggregated using a mechanic grinder (Retsch, Haan, Germany) to pass through a 2-mm sieve. Soil contents of $\mathrm{S}, \mathrm{P}, \mathrm{K}, \mathrm{Ca}, \mathrm{Mg}, \mathrm{Cd}, \mathrm{Cu}, \mathrm{Mn}$, $\mathrm{Cr}, \mathrm{Pb}, \mathrm{Ni}, \mathrm{Zn}$, As are pseudo-total aqua regia extractable contents measured by ICP-OES after microwave digestion. Soil $\mathrm{pH} \mathrm{H}_{2} \mathrm{O}$ and $\mathrm{EC}$ were measured in a 1:5 soil-to-water suspension. Total organic carbon (TOC) in the soil was measured with a TOC analyzer equipped with a solid sample module (Shimadzu 5050A Solid Sample Module Analyser, Shimadzu, Kyoto, Japan) operated at $900{ }^{\circ} \mathrm{C} . \mathrm{CaCO}_{3}$ content was determined by back-titration with $0.5 \mathrm{M} \mathrm{NaOH}$ of an excess of $\mathrm{H}_{2} \mathrm{SO}_{4}$ added to $1 \mathrm{~g}$ air-dried 
sediment. The grain size distribution of the soil samples was determined using laser diffractometry (Coulter LS200, Miami, FL, USA) with the clay fraction defined as the $0-6-\mu \mathrm{m}$ fraction. $\mathrm{SO}_{4}{ }^{2-}$ was precipitated as $\mathrm{BaSO}_{4}$ using a $10 \% \mathrm{BaCl}_{2} .2 \mathrm{H}_{2} \mathrm{O}$ solution and determined turbidimetrically with a multi-cell sample spectrophotometer (Shimadzu UV-1601, Shimadzu, Kyoto, Japan).

\subsection{Data Handling and Statistics}

The growing season was split into three periods, i.e., early (leaf samples collected in Week 18, 21 and 24), middle (leaf samples collected in Week 27, 30 and 33) and late (leaf samples collected in Week 36, 39 and 42) growing season. Each period included three samplings. The trends in foliar $\mathrm{Cd}, \mathrm{Zn}$ and $\mathrm{Mn}$ concentrations in the late growing season for the four consecutive growing seasons for Plots $1-6$ and the reference plot were analyzed with linear regression. Data were aggregated per type of plot (Plots $1+2+3$ : "dry" = plots already emerged in spring 2003; Plots $4+5+6=$ plots initially still submerged in 2003, but gradually emerging during the next years; and Plot $0=$ reference) for each sampling year. A linear model with second order interaction terms (concentration $=$ year + plot type + year:plot type) was applied. Non-significant second order interaction terms were removed from the model. A similar model was used to detect trends in cutting concentrations $(\mathrm{Cd}, \mathrm{Zn}, \mathrm{Mn})$ for the samples collected at the end of the growing season. Only the year:plot interaction was significant $(p<0.05)$ for $\mathrm{Cd}$ and $\mathrm{Mn}$ concentrations in the cuttings.

To assess whether net uptake from the soil took place in the first greenhouse trial, the amount of $\mathrm{Cd}$, $\mathrm{Zn}$ and $\mathrm{Mn}$ in the sampled compartments (Figure 4) 16 weeks after planting were compared with the initial amount of these elements in the cutting at the onset of the experiment with one-way ANOVA for both treatments separately. For the second greenhouse trial, two-way ANOVA was used for the comparison of the total amount of $\mathrm{Cd}$ and $\mathrm{Mn}$ in the cuttings before and after shoot development, i.e., initial amounts of $\mathrm{Cd}, \mathrm{Mn}$ and $\mathrm{Zn}$ were compared with the amounts in the cuttings with shoots grown on the contaminated and the uncontaminated soil (Factor 1), for the cuttings from the uncontaminated, as well as the contaminated location (Factor 2).

For greenhouse Experiment 3, the number of cuttings with signs of budburst and shoot growth were counted and expressed relative to the total number of cuttings per location $(n=20)$.

\section{Acknowledgments}

We thank the technical staff and the lab technicians at INBO for their contribution to this research. We are grateful to Miriam Levenson (ILVO) for English-language editing.

\section{Author Contributions}

Bart Vandecasteele coordinated the field monitoring and the greenhouse trials, and integrated the results in this paper. Paul Quataert helped with the statistical modelling of the metal uptake in the vegetation. Frederic Piesschaert designed the piezometer network, and performed the data processing of the monitoring of the groundwater levels. Suzanna Lettens and Bruno De Vos helped with the sampling design and the interpretation of the data on metal uptake in vegetation, and the interpretation of the 
results of the greenhouse trials. Gijs Du Laing was involved in the interpretation of the observed trends in metal uptake in the vegetation and its link with hydrology and soil chemistry.

\section{Conflicts of Interest}

The authors declare no conflicts of interest.

\section{References}

1. Kuzovkina, Y.A.; Quigley, M.F. Willows beyond wetlands: Uses of Salix L. species for environmental projects. Water Air Soil Pollut. 2005, 162, 183-204.

2. Gage, E.A.; Cooper, D.J. Controls on willow cutting survival in a montane riparian area. J. Rangeland Ecol. Manag. 2004, 57, 597-600.

3. Bourret, M.M.; Brummer, J.E.; Leininger, W.C.; Heil, D.M. Effect of water table on willows grown in amended mine tailing. J. Environ. Qual. 2005, 34, 782-792.

4. Schrama, M.; Vandecasteele, B.; Carvalho, S.; Muylle, H.; van der Putten, W.H. Effects of first and second generation bioenergy crops on soil processes and legacy effects on a subsequent crop. GCB Bioenergy 2015, doi:10.1111/gcbb.12236.

5. Tahvanainen, L.; Rytkonen, V.M. Biomass production of Salix viminalis in southern Finland and the effect of soil properties and climate conditions on its production and survival. Biomass Bioener. 1999, 16, 103-117.

6. Tack, F.M.G.; Vandecasteele, B. Cycling and ecosystem impact of metals in contaminated calcareous dredged sediment-derived soils (Flanders, Belgium). Sci. Total Environ. 2008, 400, 283-289.

7. Talbot, R.J.; Etherington, J.R.; Bryant, J.A. Comparative-studies of plant-growth and distribution in relation to waterlogging. 12. Growth, photosynthetic capacity and metal-ion uptake in Salix caprea and Salix cinerea ssp oleifolia. New Phytol. 1987, 105, 563-574.

8. Iremonger, S.F.; Kelly, D.L. The responses of four Irish wetland tree species to raised soil water levels. New Phytol. 1988, 109, 491-497.

9. Barrick, K.A.; Noble, M.G. The iron and manganese status of seven upper montane tree species in Colorado, USA, following long-term waterlogging. J. Ecol. 1993, 81, 523-531.

10. Shabala, S.; Shabala, L.; Barcelo, J.; Poschenrieder, C. Membrane transporters mediating root signalling and adaptive responses to oxygen deprivation and soil flooding. Plant Cell Environ. 2014, 37, 2216-2233.

11. Boyter, M.J.; Brummer, J.E.; Leininger, W.C. Growth and metal accumulation of geyer and mountain willow grown in topsoil versus amended mine tailings. Water Air Soil Pollut. 2009, 198, 17-29.

12. Yang, W.; Ding, Z.; Zhao, F.; Wang, Y.; Zhang, X.; Zhu, Z.; Yang, X. Comparison of manganese tolerance and accumulation among 24 Salix clones in a hydroponic experiment: Application for phytoremediation. J. Geochem. Explor. 2015, 149, 1-7.

13. Vandecasteele, B.; Du Laing, G.; Tack, F.M.G. Effect of submergence-emergence sequence and organic matter or aluminosilicate amendment on metal uptake by woody wetland plant species from contaminated sediments. Environ. Pollut. 2007, 145, 329-338. 
14. Vandecasteele, B.; Du Laing, G.; Lettens, S.; Jordaens, K.; Tack, F.M.G. Influence of flooding and metal immobilising soil amendments on availability of metals for willows and earthworms in calcareous dredged sediment-derived soils. Environ. Pollut. 2010, 158, 2181-2188.

15. Bourret, M.M.; Brummer, J.E.; Leininger, W.C. Establishment and growth of two willow species in a riparian zone impacted by mine tailings. J. Environ. Qual. 2009, 38, 693-701.

16. Thomas, F.M.; Sprenger, S. Responses of two closely related oak species, Quercus robur and $Q$. petraea, to excess manganese concentrations in the rooting medium. Tree Physiol. 2008, 28, 343-353.

17. Shanahan, J.O.; Brummer, J.E.; Leininger, W.C.; Paschke, M.W. Manganese and zinc toxicity thresholds for mountain and Geyer willow. Int. J. Phytorem. 2007, 9, 437-452.

18. El-Jaoual, T.; Cox, D.A. Manganese toxicity in plants. J. Plant Nutr. 1998, 21, 353-386.

19. Kitao, M.T.T.; Leia, M.; Nakamuraa, T.; Koikea, T. Manganese toxicity as indicated by visible foliar symptoms of Japanese white birch (Betula platyphylla var. japonica). Environ. Pollut. 2001, 111, 89-94.

20. Vandecasteele, B.; Quataert, P.; Tack, F.M.G. Uptake of Cd, Zn and Mn by willow increases during terrestrialisation of initially ponded polluted sediments. Sci. Total Environ. 2007, 380, 133-143.

21. Vermeulen, J.; van Gool, M.P.M.; Dorleijn, A.S.; Joziasse, J.; Bruning, H.; Rulkens, W.H.; Grotenhuis, J.T.T. Biochemical ripening of dredged sediments. Part 1. Kinetics of biological organic matter mineralization and chemical sulfur oxidation. Environ. Toxicol. Chem. 2007, 26, 2530-2539.

22. Vandecasteele, B.; Quataert, P.; Genouw, G.; Lettens, S.; Tack, F.M.G. Effects of willow stands on heavy metal concentrations and top soil properties of infrastructure spoil landfills and dredged sediment-derived sites. Sci. Total Environ. 2009, 407, 5289-5297.

23. Du Laing, G.; de Meyer, B.; Meers, E.; Lesage, E.; van de Moortel, A.; Tack, F.M.G.; Verloo, M.G. Metal accumulation in intertidal marshes along the river Scheldt: Role of sulfide precipitation. Wetlands 2008, 28, 735-746.

24. Du Laing, G.; Meers, E.; Dewispelaere, M.; Vandecasteele, B.; Rinklebe, J.; Tack, F.M.G.; Verloo, M.G. Heavy metal mobility in intertidal sediments of the Scheldt estuary: Field monitoring. Sci. Total Environ. 2009, 407, 2919-2930.

25. Du Laing, G.; Meers, E.; Dewispelaere, M.; Rinklebe, J.; Vandecasteele, B.; Verloo, M.G.; Tack, F.M.G. Effect of water table level on metal mobility at different depths in wetland soils of the Scheldt estuary (Belgium). Water Air Soil Pollut. 2009, 202, 353-367.

26. Du Laing, G.; Vanthuyne, D.R.J.; Vandecasteele, B.; Tack, F.M.; Verloo, M.G. Influence of hydrological regime on pore water metal concentrations in a contaminated sediment-derived soil. Environ. Pollut. 2007, 147, 615-625.

27. Stephens, S.R.; Alloway, B.J.; Parkern, A.; Cartern, J.E.; Hodson, M.E. Changes in the leachability of metals from dredged canal sediments during drying and oxidation. Environ. Pollut. 2001, 114, 407-413.

28. Maxted, A.P.; Black, C.R.; West, H.M.; Crout, N.M.J.; McGrath, S.P.; Young, S.D. Phytoextraction of cadmium and zinc by Salix from soil historically amended with sewage sludge. Plant Soil 2007, $290,157-172$. 
29. Unterbrunner, R.; Puschenreiter, M.; Sommer, P.; Wieshammer, G.; Tlustos, P.; Zupan, M.; Wenzel, W.W. Heavy metal accumulation in trees growing on contaminated sites in Central Europe Environ. Pollut. 2007, 148, 107-114.

30. Nissen, L.R.; Lepp, N.W. Baseline concentrations of copper and zinc in shoot tissues of a range of Salix species. Biomass Bioenerg. 1997, 12, 115-120.

31. Vandecasteele, B.; Willekens, K.; Zwertvaegher, A.; Degrande, L.; Tack, F.M.G.; Du Laing, G. Effect of composting on the $\mathrm{Cd}, \mathrm{Zn}$ and $\mathrm{Mn}$ content and fractionation in feedstock mixtures with wood chips from a short-rotation coppice and bark. Waste Manag. 2013, 33, 2195-2203.

32. Vollenweider, P.; Cosio, C.; Günthard-Goerg, M.; Keller, C. Localization and effects of phyto-extracted cadmium in leaves of tolerant willows (Salix viminalis L.) II. Microlocalization and cellular effect of cadmium. Environ. Exp. Botany 2006, 58, 25-40.

33. Lepp, N.W.; Madejón, P. Cadmium and zinc in vegetation and litter of a voluntary woodland that has developed on contaminated sediment-derived soil. J. Environ. Qual. 2007, 36, 1123-1131.

34. King, R.F.; Royle, A.; Putwain, P.D.; Dickinson, N.M. Changing contaminant mobility in a dredged canal sediment during a three-year phytoremediation trial. Environ. Pollut. 2006, 143, 318-326.

35. Du Laing, G.; Bontinck, A.; Samson, R.; Vandecasteele, B.; Vanthuyne, D.R.J.; Meers, E.; Lesage, E.; Tack, F.M.G.; Verloo, M.G. Effect of decomposing litter on the mobility and availability of metals in the soil of a recently created floodplain. Geoderma 2008, 147, 34-46.

36. Lei, Y.; Korpelainen, H.; Li, C. Physiological and biochemical responses to high Mn concentrations in two contrasting Populus cathayana populations. Chemosphere 2007, 68, 686-694.

37. Kozlov, M.V.; Eränen, J.K.; Zverev, V.E. Budburst phenology of white birch in industrially polluted areas. Environ. Pollut. 2007, 148, 125-131.

38. Punshon, T.; Dickinson N.M. Acclimation of Salix to metal stress. New Phytol. 1997, 137, 303-314.

39. Mleczek, M.; Łukaszewski, M.; Kaczmarek, Z.; Rissmann, I.; Golinski, P. Efficiency of selected heavy metals accumulation by Salix viminalis roots. Environ. Exp. Bot. 2009, 65, 48-53.

(C) 2015 by the authors; licensee MDPI, Basel, Switzerland. This article is an open access article distributed under the terms and conditions of the Creative Commons Attribution license (http://creativecommons.org/licenses/by/4.0/). 